\title{
To What Extent Can Long-Term Investment in Infrastructure Reduce Inequality?
}

\author{
Emma Hooper ${ }^{1}$, Sanjay Peters ${ }^{2}$ \& Patrick A. Pintus ${ }^{3}$ \\ Working Paper \# 624
}

\author{
March 2017
}

\begin{abstract}
By reviewing US state-level panel data on infrastructure spending and on per capita income inequality from 1950 to 2010, this paper sets out to test whether there is an empirical link between infrastructure and inequality. Our main result, obtained from panel regressions with both state and time fixed effects, shows that highways and higher education spending growth in a given decade correlates negatively with Gini indices at the end of the decade. Such a finding suggests a causal effect from growth in infrastructure spending to a reduction in inequality, through better access to job and education opportunities. More significantly, this relationship is stronger with inequality at the bottom 40 per cent of the income distribution. In addition, infrastructure expenditures on highways are shown to be more effective at reducing inequality. A counterfactual experiment reveals which US states ended up with a significantly higher bottom Gini coefficient in 2010 that is attributed to underinvestment in infrastructure over the first decade of the 21st century. From a policy making perspective, this paper aims to present innovations in finance for infrastructure investments, for the US, other industrially advanced countries and also for developing economies.
\end{abstract}

Keywords: Public Infrastructure, Education, Highways, Income Inequality, US State Panel Data, Fixed Effects Models.

JEL classification: C23, D31, H72, 124, 051.

\footnotetext{
${ }^{1}$ Aix-Marseille University, emmahooper@hotmail.fr

${ }^{2}$ Columbia University, sp3157@columbia.edu

${ }^{3}$ Banque de France, patrick.pintus@banque-france.fr
}

Working Papers reflect the opinions of the authors and do not necessarily express the views of the Banque de France. This document is available on the Banque de France Website. 


\section{NON-TECHNICAL SUMMARY ${ }^{4}$}

Long-term investments in infrastructure are now at the center of many policy initiatives worldwide. In particular, many global institutions are betting on the development of infrastructure to pave the way for future growth, both in developed countries as well as in developing countries. The most noteworthy initiatives linked to infrastructure that have attracted a lot of interest in the media and are debated at a policy-making level include the launch of the Asian Infrastructure Investment Bank (AlIB) under the leadership of China. In Europe, the Juncker Plan as well as several actions that have been undertaken by the European Investment Bank (EIB) and by the European Bank for Reconstruction and Development (EBRD) to promote infrastructure investment can be seen as a vehicle to resuscitate the European Union project. In addition, the World Bank, through its Global Infrastructure Facility (GIF), has designed a platform to channel funds to rich as well as developing countries, while numerous global investment banks such as Goldman Sachs and J.P. Morgan have set up infrastructure investment divisions within their operations. Infrastructure financing also surfaced as a major topic during the recent US election, with explicit infrastructure plans proposed by both the Clinton and Trump camp.

While there is growing belief about the potential benefits of public infrastructure, which include highways, bridges, ports, transportation networks, telecommunications systems and community colleges, one is struck by the lack of empirical evidence which supports such a claim. More specifically, little is known about the ability of infrastructure to ensure that the proceeds from enhanced growth, if any, are distributed among society in a fair way. The literature about the empirical link between inequality and growth is well developed, however the existence of a possible relationship between infrastructure and income distribution is negligible or obsolete in the discourse. This research gap is felt most acutely in the US context, where the damaging impact of rising inequality has become a major policy issue. In addition, physical infrastructure in the US is admittedly in urgent need of maintenance and upgrading. The burgeoning literature on the subject suggests that the growing deterioration of infrastructure is having an adverse effect on per capita GDP and GDP growth, and possibly also on physical quality of life and well-being. However, very little is known about whether a lack of infrastructure spending affects inequality. The latter theme is the main focus of our inquiry.

This paper makes three noteworthy contributions to broaden the literature on infrastructure to determine if it can be used to reduce inequality, in addition to stimulating economic growth. By using US state-level data on infrastructure spending and per capita income inequality from 1950 to 2010, the paper looks at whether an empirically verifiable link exists between infrastructure and inequality. One of the main findings is that highways and higher education spending growth in a given decade correlates significantly and negatively with income inequality at the end of the decade. Such a result is suggestive of a causal effect from growth in infrastructure spending to inequality. We find that this

\footnotetext{
${ }^{4}$ The authors would like to especially thank Branko Milanovic and Roy van der Weide to allow access to their data set on income inequality, and to Camille Hémet, our discussant at Banque de France, for very useful feedback and suggestions. We are grateful to Philippe Aghion, Gilbert Cette, Erika Dayle Siu, Martin Fiszbein, Martin Guzman, Daniel Heymann, Claire Lelarge, Omar Licandro, José Antonio Ocampo, Thomas Piketty, Emmanuel Saez for constructive comments. We are also indebted to participants at the 2016 RIDGE Buenos Aires workshop on Macroeconomics, Development and Structural Change and at Columbia University for helpful feedback. Lastly, we thank Craig A. Langley at the US Census Bureau office for very helpful assistance with US state level data. First Draft: September 14, 2016. The usual disclaimer applies.
} 
relationship is stronger with inequality at the bottom $40 \%$ of the income distribution and also for spending on highways. Secondly, we use those results to conduct a counterfactual experiment that reveals which US states ended up with a significantly higher inequality level in 2010 due to underinvestment in infrastructure over the first decade of the 21st century (see Figure). Lastly, from a policy making perspective, the paper draws attention the innovations in finance for infrastructure investments, for the US, other industrially advanced countries and also for developing economies.

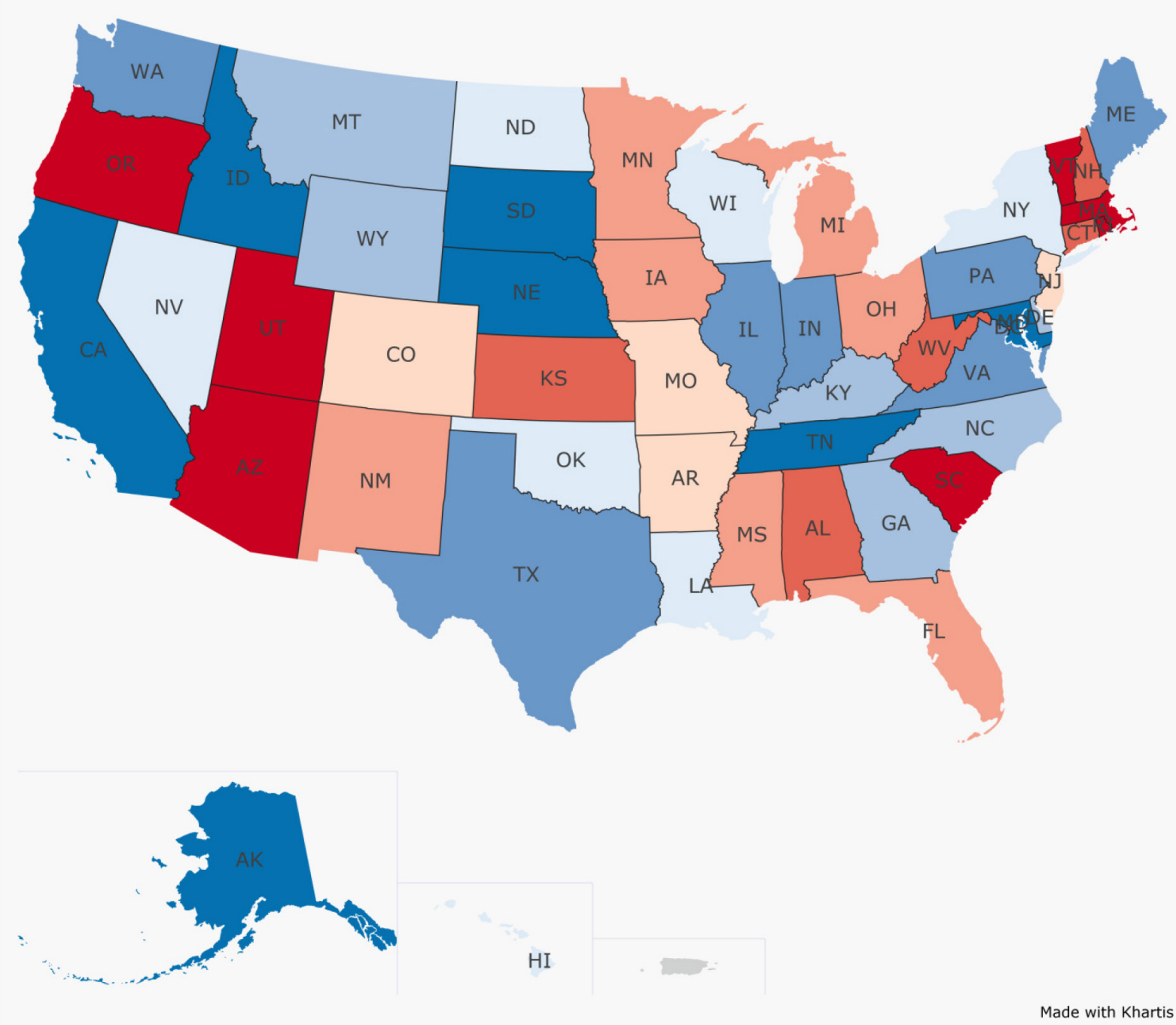

Figure: US States with rising inequality in 2010 attributed to underinvestment in highways over 200010 appear in Red; US States with reduced inequality in 2010 attributed to strong investment in highways over 2000-10 appear in Blue (darker colors indicate larger variations). 


\section{Résumé: L'investissement dans les infrastructures de long-terme contribue-t-il à réduire les inégalités de revenu ?}

À partir de données de panel relatives aux états fédéraux des États-Unis pendant la période 19502010, notre étude a pour objet de tester l'existence d'une possible relation empirique entre dépenses publiques en infrastructure et inégalités de revenu. Notre principal résultat, obtenu à partir d'estimations en panel avec des effets fixes état et année, établit que le taux de croissance annuel des dépenses consacrées à l'éducation supérieure et au réseau autoroutier pendant une décennie donnée est négativement corrélé avec l'indice de Gini à la fin de cette même décennie. Une telle relation suggère un effet causal de l'investissement en infrastructure vers les inégalités de revenu. Cet effet de réduction des inégalités s'avère plus fort sur les $40 \%$ des revenus les plus bas dans la distribution. Par ailleurs, investir dans le réseau autoroutier réduit plus sensiblement les inégalités que les dépenses d'éducation supérieure. Nous utilisons ces estimations en panel afin de conduire une expérience contrefactuelle nous conduisant à identifier quels sont les états fédéraux qui ont connu un niveau d'inégalité plus élevé en 2010 du fait d'un sous-investissement en infrastructure pendant la décennie 2000-10. Dans une perspective de décision publique, nous présentons puis discutons également plusieurs innovations qui devraient à l'avenir permettre de considérablement stimuler le financement des investissements de long-terme en infrastructure, pour les USA, l'ensemble des pays développés ainsi que les pays en développement.

Mots-clés : Infrastructure publique, Éducation, Autoroutes, Inégalités de revenu, Données de panel US, Modèle à effets fixes. 


\section{Introduction}

Long-term investments in infrastructure are currently at the center of many policy initiatives worldwide. In particular, many global institutions are betting on the development of infrastructure to pave the way for future growth. In developed countries, the hope is to reverse a much feared "secular stagnation" by better maintenance of existing public goods and more importantly by investing in infrastructure that fosters innovation while at the same time protecting the environment. In developing countries, on the other hand, electrification as well as hospitals and railways construction are central during election campaigns, most prominently in Africa. Additionally, investment in infrastructure is needed to ensure that economic improvement continues in the many countries that have benefitted from a significant reduction in violent conflicts. The most noteworthy initiatives linked to infrastructure that have attracted a lot of interest in the media and are debated at a policy-making level include, the launch of the Asian Infrastructure Investment Bank (AIIB) under the leadership of China. In Europe, the Juncker Plan as well as several actions that have been undertaken by the European Investment Bank (EIB) and by the European Bank for Reconstruction and Development (EBRD) to promote infrastructure investment can be seen as a vehicle to resuscitate the European Union project. In addition, the World Bank, through its Global Infrastructure Facility (GIF), has designed a platform to channel funds to mature as well as developing countries, while numerous global investment banks such as Goldman Sachs and J.P. Morgan have now set up infrastructure investment divisions within their operations. Last but not least, infrastructure financing surfaced as a major topic in the recent US election, with explicit infrastructure plans proposed by both the Clinton and Trump camp.

While there is growing belief about the potential benefits of public infrastructure, which include highways, bridges, ports, transportation networks, telecommunications systems and community colleges, one is struck by the lack of empirical evidence which supports such a claim. More specifically, little is known about the ability of infrastructure to ensure that the proceeds from enhanced growth, if any, are distributed among society in a fair way. The literature about the empirical link between inequality and growth is well developed, however the existence in the data of a possible relationship between infrastructure and income distribution is negligible or obsolete in the discourse. This research gap is felt most acutely in the US context, where the damaging impact of rising inequality has become a major policy issue. In addition, physical infrastructure in the US is admittedly in urgent need of maintenance and upgrading. The literature on the subject suggests that the growing deterioration of infrastructure is having an adverse effect on per capita GDP and GDP growth, and possibly also on physical quality of life and well-being. However, very little is known about whether a lack of infrastructure spending affects inequality. The latter theme is the main focus of our inquiry.

In short, the inequality-growth nexus has turned out to be a hard empirical nut to crack. While the bulk of the literature which flourished during the early 1990s, surveyed by Bénabou (1996), tends to support the view that higher inequality typically slows down growth, more recent studies by Forbes (2000) and Li and Zou (1998) challenge this argument. Atkinson and Bourguignon (2015) for example argue that important nuances are missing by relying extensively on aggregate data to study the relationship between economic growth and inequality. The current trend therefore has been to focus instead on disaggregated data across different deciles of the distributions. A departure from the previous path can be seen in Thomas Piketty's Capital in the 21st Century (2014), generating enormous public interest on the subject of inequality and growth at a global level. Milanovic (2016) uses global survey data, while van der Weide and Milanovic (2014) employ 
micro-census data from US states to show that high levels of inequality reduce the income growth of the poor but help the growth of the rich. One of the main policy solutions put forward to address the problem of rising inequality, particularly by Piketty, is to increase the income tax, especially at the top end of the income and wealth distribution to make it more progressive. The belief is that raising income tax among the wealthiest segments of society, at a global level, would enable governments to both increase in-kind and monetary transfers and also invest more on public goods for the majority of the population. While the literature on the impact of transfers on inequality is gaining a lot of visibility, research about the extent to which infrastructure investments may effect inequality, however, is glaringly sparse.

This paper has two main objectives. The first is to empirically test whether there is any correlation between infrastructure investments and income inequality, and more specifically to evaluate the extent to which infrastructure investments may have a differential effect on top and bottom inequality. The focus of earlier studies has been on highlighting the negative relationship between inequality and growth produced by the wealthiest segment of the income distribution opting out from the financing of public infrastructure projects. In spite of its intuitive appeal, such a postulation has not been put to empirical scrutiny. On the other hand, how inequality at the bottom end of the income distribution correlates with infrastructure appears to be ambiguous on a priori grounds. This is due to the fact that while more bottom inequality could be explained by lack of public services such as education, it also calls for more redistributive transfers that could possibly crowd out spending on long-term investment in infrastructure. More importantly, while the literature has focused on the direction of causality for infrastructure outcome as being shaped by inequality, it is equally plausible that investment in infrastructure improves geographical mobility and reduces inequality.

Our aim here is to try to address these pressing issues by reviewing and analyzing US state-level panel data. The main motivation for selecting US states, apart from having easier access to reliable data, is that there are significant differences in how both inequality and infrastructure spending vary over time across US states. Such variations offer the possibility to uncover any robust relationship between infrastructure and inequality. In addition, the data allow us to test for such a relationship by taking different types of infrastructure into account such as transportation, education, health related areas, judicial, cultural and legal. Our data on overall, bottom and top Gini indices on income distribution are derived from van der Weide and Milanovic (2014), who use six waves of the Integrated Public Use Microdata Series (IPUMS), for 1960, 1970, 1980, 1990, 2000 and 2010. For infrastructure spending, we have constructed real growth rates by relying on data from the US Census Bureau, that provide an annual survey of state and local government finances from 1951 to 2008. By using US state-level data on both infrastructure spending and per capita income inequality over a 60 year period, from 1950 to 2010, this paper sets out to test if there is an empirically verifiable link between infrastructure and inequality. Our main finding, obtained from panel regressions with state and time fixed effects, is that highways and higher education spending growth in a given decade correlates significantly and negatively with Gini indices at the end of the decade, suggesting a causal effect from growth in infrastructure spending to inequality. We find that this relationship is stronger with inequality at the bottom $40 \%$ of the income distribution and also for highways spending. Our tentative explanation of the latter feature comes from the observation that spending on highways has declined in many states over the period between 1950 and 2010, thus worsening income inequality by making up to secondary level education and job opportunities more difficult to access. In contrast, higher education spending has grown faster and has almost never declined in any state. The data and empirical strategy are described in Section 3, while Section 4 offers a 
discussion on our main empirical results, including a counterfactual exercise that helps identify the states which experience larger income inequality because of underinvestment in infrastructure. ${ }^{1}$

The negative correlation that we document - between Ginis in year $t$ and growth rates of spending on infrastructure in the decade preceding year $t$ - arguably suggests a causal effect from growth in infrastructure spending to inequality. In other words, US states with high growth rates of spending on highways or higher education enjoy lower inequality a decade down the road. Causality, however, is argued to go in the opposite direction in the existing debate and literature on inequality and growth. The conventional wisdom is that states with high inequality (especially bottom inequality) have lower growth rates of infrastructure spending, either because the richest segment of the income distribution plays no major role in financing of infrastructure or because larger inequality triggers more transfers that crowd out infrastructure investments. In order to test this assumption, we run regressions of growth rates on infrastructure spending on lagged Ginis, together with state and year fixed effects, and we find that coefficients on lagged Ginis are not significant. Our data provide no evidence of past inequality having an adverse effect on future infrastructure spending. In contrast, we do find that past infrastructure spending is associated with less inequality at the end of the decade. Our results therefore support the argument that investments in infrastructure contribute to enlarge geographical mobility and hence to reduce inequality.

The second key objective of our paper is to present a set of possible solutions to alleviate the many obstacles to fund infrastructure investments in developing as well as developed countries. The negative - and highly significant - relationship between infrastructure spending and inequality that we document in the first part of this paper suggests that boosting public investment could help ameliorate the US income distribution. However, the US, like many other countries, has accumulated high levels of government deficit and public debt, and that may put a tight limit on the scale of any plan to enhance infrastructure. In Section 5, we offer a discussion of three key pillars that could help mitigate the barriers to fund infrastructure. We first draw attention to the growing reliance on Public Private Partnerships (PPPs). Secondly, we critically review the positive impact Multilateral Development Banks and infrastructure investment platforms may have for both investors as well as host governments to obtain higher returns on investment, finance environmentally sound infrastructure projects and to potentially reduce inequality, specially for the bottom decile. Finally, we provide a set of strategies and incentives for global corporations in partnership with governments to redirect corporate tax revenues into infrastructure spending, that would otherwise be evaded or avoided.

The paper is organized as follows. Section 2 offers some stylized facts regarding rising inequality and the infrastructure funding gap in the US. Section 3 describes the data and empirical strategy that we employ, while Section 4 reports our main results about the relationship between income inequality and infrastructure spending growth. Section 5 discusses key policy proposals about how to fund infrastructure investment, that relate to our main empirical results. Finally Section 6 is dedicated towards making some concluding remarks and offering suggestions for future research.

\footnotetext{
${ }^{1}$ A few papers study the empirical relationship between infrastructure and inequality, typically by pooling aggregate data from both developed and developing countries. See Calderón and Servén (2014) for a survey. However, Wolff and Zacharias (2007) is the only paper - we know of - that looks at US household-level data to uncover such a link. The major difference with our work is that Wolff and Zacharias (2007) focus on two years, 1989 and 2000, and on public consumption while our study covers a longer period and uses data on capital outlays. They find that public consumption is very progressive and that total government expenditures, including on education and on highways, are far more potent in their inequality-reducing effect than taxes.
} 


\section{Issues at Stake in the United States}

\section{$2.1 \quad$ Rising Inequality}

Rising global inequality, especially over the past 20 years, is arguably having the most damaging effect on economic growth, political and social stability in poor, transition, as well as in industrially advanced economies. The results of the 2016 US elections, Brexit, the political instability in Venezuela and the growing migrant crisis in Europe could all be viewed as manifestations of inequality reaching breaking point. The widening gap between the rich and poor is increasingly fueling major social unrest that could have long-term implications not just on a national and regional level scale, but also a global level. Stiglitz (2012) points out that the US economy has grown over the past three decades, but the incomes of the middle class have remained stagnant, while the incomes of 1 percent of the population has steadily risen, even during the peak of the 2007-08 global economic recession. Piketty, Saez and Zucman (2016) also show that the share of total income in the US has risen by two fold for 1 percent of top earners during 1980-2014, while the bottom 50 percent has experienced no increase in three and half decades (see Figure 1).

Figure 1: Rising Inequality in the US

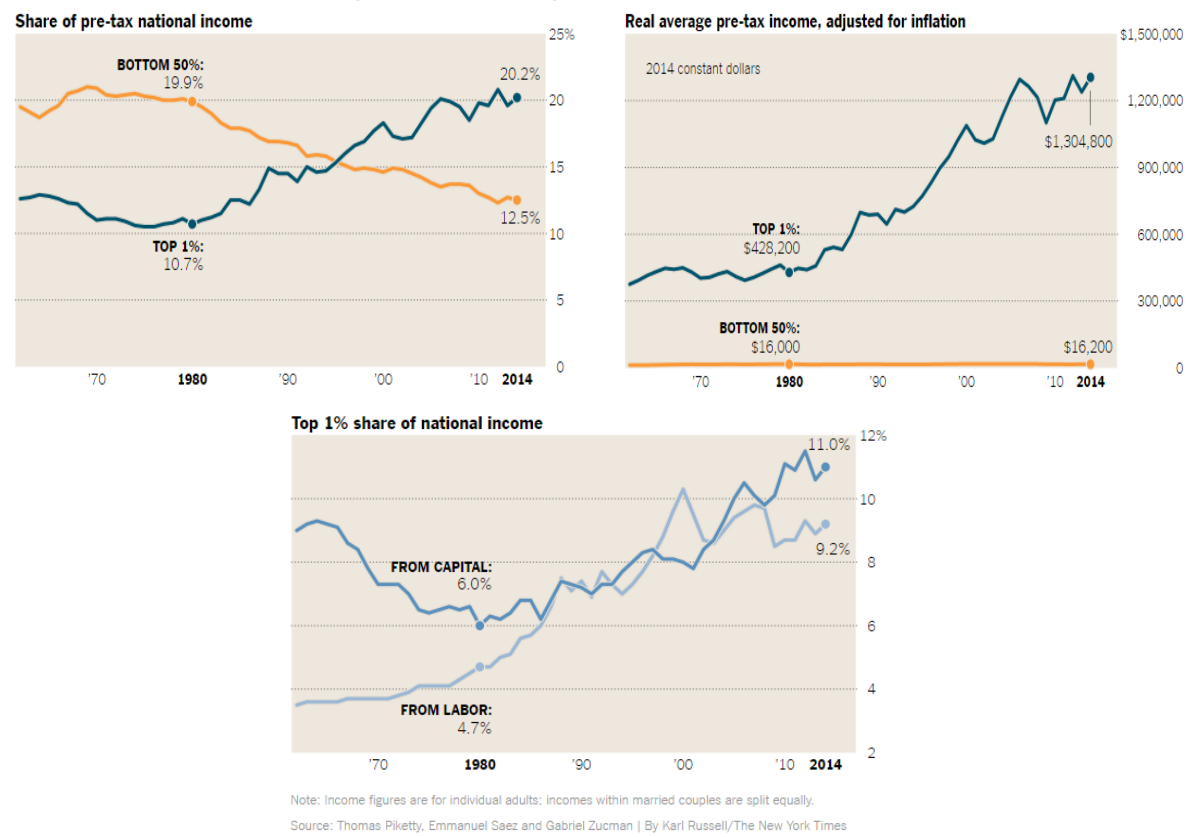

The widening gap between the very rich and the lowest income earners produce different types of social and political strains on countries, as well as regions and states within countries. d'Hombres et al. (2012) argue that, inequality can result in political apathy and reduce voter participation amongst the lowest income earners, often representing the largest percentage of the population. As a consequence, redistributive measures and efforts to reduce income disparities undertaken by policy makers are ascribed very low priority or left off the political agenda altogether. Income inequality also raises criminal activity within the poorest segments of society when comparing their living standards with the wealthiest 1-10 percent of the population.

"The relevance of the widening of income has not only caught the political and scholarly attention but is heavily discussed nowadays on the streets, with most prominent 
manifestation of such protests being the 'Occupy Wall Street'- movement. This movement and its widely-cited slogan "We are the 99\%" (see for instance the reporting of the movement by the New York Times, 2011, and also the web blog "We are the 99 percent", 2012) refers specifically to a growing unequal distribution of wealth" (ibid; 2012).

Inequality in access to education also has an adverse affect on income earning potential. The positive effect of education on growth is no longer a mere conjecture but is well supported by empirical evidence. Gary Becker's theory on human capital (1964) shows that education gains can lead to increases in the competencies of individuals and thus enhance their ability to contribute to productivity growth. Given that higher productivity tends to lead to higher wages, the argument is that a more educated society would contribute substantially to higher overall economic growth and also reduce income inequality.

The concept of inequality is relatively easy to grasp, but the real challenge lies in being able to implement appropriate policy measures and to empirically test its impact on long sustainable economic growth, or to determine whether causation runs in the opposite direction. This section provides a brief summary of the main debates on inequality and sets out to link the discussion to the possible relationship between infrastructure and inequality across US states over the past 50 years, given that it is the main focus of our research.

The relationship between inequality and economic growth continues to be a contentious issue. The early work by Simon Kuznets (1955), for example, claims that income inequality increases during early stages of economic development, generated by industrialization and that this process declines at later stages. Kaldor (1960) too argues that countries are confronted with a tradeoff between achieving economic growth and reducing inequality. This was the widely held view amongst economists five decades ago (cited in Bahety et al, 2012). Fields (2001) however argues that the inverted "U" shaped Kuznets curve is not backed up by empirical data. Instead, he maintains that the type of economic growth is what determines whether inequality increases or declines over time, as apposed to stages of industrial development. In sum, Kanbur and Stiglitz (2015), argue that the earlier Kuznets and Kaldor models are outdated in the current context of the global economy. "The new models need to drop competitive marginal productivity theories of factor returns in favour of rent-generating mechanism and wealth inequality by focusing on the rules of the game."

A prominent view at present (see Bourguignon; 1996, Kanbur and Lustig, 1999, Stern, 1991, Atkinson, 1997, Berg, Loungani and Ostry, 2017) is that a more equitable initial distribution of income and assets determine long-term economic growth, and that redistribution, albeit without any guarantee, could make an important contribution to facilitate sustainable economic growth. Both Bourgignon (2000) and Piketty (2014) propose progressive increases in the taxation of incomes of the 1 percent of the highest earners to redistribute wealth and reduce inequality as well as to achieve long-term growth (see latter section of the paper on corporate tax avoidance and evasion). Based on more recent literature, the direction of causation is shown to run in the opposite direction as put forward by the Kuznets Curve, from inequality reduction to growth. A further extension of this argument is highlighted in the discussion on financial market imperfections having an adverse effect on initial distribution of wealth and long-term rate of economic growth (see, Aghion and Bolton, 1992 and 1997; Banerjee and Newman, 1993; Galor and Zeira, 1993 and Piketty, 1997). According to adherents of this view, the practice of credit rationing is made on the basis of initial wealth endowment of individual agents who invest in human and physical capital. The problem is that there are enormous differences in the initial endowment of wealth among individuals (inherited from parents) and this heterogeneity is said to shape their investment opportunities (cited in Ehrhart, 
2009).

A case study which measures the impact of infrastructure investments on inequality at a regional level in India by Bajar and Rajeev (2015) shows that certain elements of infrastructure such as power and roads tend to exacerbate inequality rather than reduce it. This is due to the fact that public goods are allocated at a flat, albeit subsidized rate across the board, which helps those who are already better endowed with higher incomes and own expensive cars and durable goods such as fridges and televisions. The newly built or improved roads merely enable the more economically well off in rural regions of India to gain easier access to markets. The poorest groups also benefit from the access to improved or new roads, but much less in comparative terms. All farmers, for example are charged a flat rate for electricity, mainly used for pumping water, but this tends to benefit large land owners more than small scale farmers. Leakages as well as poorly designed policy measures are the main barriers to mitigate inequality at a regional level in India through infrastructure investments. A study by Lee et al. (2016) on rural electrification projects in Kenya also reveals similar leakages and the costs of such government programs to outweigh the benefits.

Ashauer's (1989) groundbreaking paper meanwhile reveals that public infrastructure increases total factor productivity in the US. Subsequently, several empirical research papers at a country level have emerged showing that infrastructure positively affects economic growth (see Bom and Ligthart, 2008, and Romp and De Haan, 2007). Cross-country comparative research by Calderon and Serven (2004) and Calderon and Chong (2004) concur with such findings, and argue that infrastructure can at least partially help reduce inequality (cited in Gibson and Roja, 2014). These mixed results stress the need for greater empirical scrutiny to determine the nature of the relationship between infrastructure and inequality. They also draw attention to the challenges involved in trying to establish a general pattern in infrastructure spending for reducing inequality across all countries, regions or states within countries.

\subsection{The Infrastructure Funding Gap}

The American Society of Civil Engineers, in its 2013 Report Card for America's Infrastructure, estimates the cost of bringing US infrastructure from a poor grade to a state of good repair (from D+ to B) to be about $\$ 3.6 \mathrm{tr}$, of which only $56 \%$ is funded. Figure 2 shows that surface transportation and school infrastructure are the items with the largest funding gap (\$846bn and $\$ 271 \mathrm{bn}$, respectively). Combined together, surface transportation and schools infrastructure account for $69 \%$ of the US funding gap estimated to be about $\$ 1.6$ tr (ibid ASCE, 2013).

State and Local governments own the vast majority of public capital (about 96\% in 2014 according to the Bureau of Economic Analysis) and account for nearly $75 \%$ of total spending designed to maintaining and improving public infrastructure in 2004 (Congressional Budget Office). Schools and surface transportation represent about two thirds of capital spending by state and local governments. While most of the public funding is provided by state and local governmental institutions, it does not mean that the federal government does not play any role in funding infrastructure. For example, it has been well documented that when states received a federal highways grant from the 2009 American Recovery and Reinvestment Act (ARRA), they increased highways spending from 2009 to 2011 by more than dollar-for-dollar with the grant they received (Leduc and Wilson, 2013). Such "flypaper effect" suggests that federal funding has a multiplier effect on state funding and, hence, the federal government could stimulate and foster major infrastructure projects. ${ }^{2}$ However, most

\footnotetext{
${ }^{2}$ Dupor and Mehkari (2015) show that the education component of the ARRA increased expenditures on public
} 
Figure 2: Infrastructure needs, funded and unfunded from 2013 to 2020

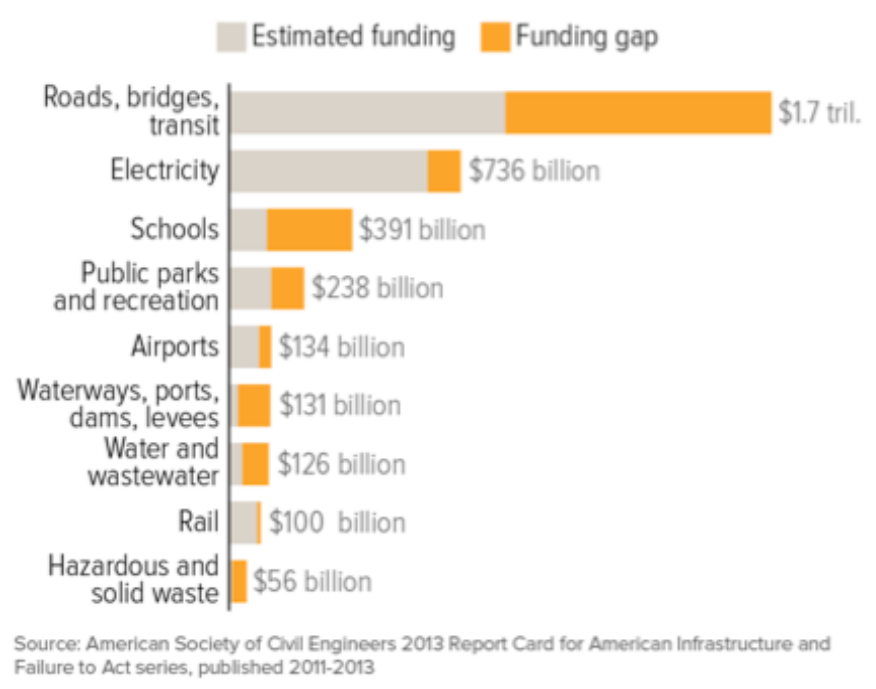

of this and other related episodes seem to be associated with stimulus plans that aim at boosting economic activity in recession times. This pattern of federal funding would suggest that they would likely dry up during periods of economic recovery and expansion. In Section 5, we further discuss how financial innovation can spur long-term commitments to fund infrastructure, over and above counter-cyclical fiscal policy at the federal level.

If one takes a longer-term perspective, two features stand out. First, federal infrastructure spending has fallen from 1 percent to 0.5 percent of GDP over the last 35 years. Second, a similar downward trend has also been noted at the state level, which shows that state and local spending on infrastructure is at a 30-year low and went down from about 3\% of GDP at the end of the 1960s to below $2 \%$ of GDP in 2014, according to BEA data.

\section{Data and Empirical Strategy}

The purpose of this section is to examine how inequality may be related to infrastructure spending, using US state-level data. More specifically, the aim is to test whether more inequality in year $t$ is associated with a decline in infrastructure spending growth over the decade prior to year $t$.

As for our dependent variable, we use the data provided by van der Weide and Milanovic (2014) on state-level Gini coefficients of income inequality, which are constructed using six waves of the Integrated Public Use Microdata Series (IPUMS, see Ruggles et alii, 2015), 1960, 1970, 1980, 1990, 2000 and 2010. The main advantage of their data is that it breaks down the overall Gini into a bottom Gini (lower $40 \%$ end of the income distribution) and a top Gini (top 40\%). This allows detecting possible differential effects of infrastructure spending on inequality at the bottom and top ends of the income distribution. Income is defined per household member and in real terms, and it includes wages and other salary, self-employment income, financial revenues, pensions, public assistance and welfare transfers, and other regular incomes such as unemployment benefit.

Our state-level data on infrastructure have been obtained from the US Census Bureau, which provides an Annual Survey of State and Local Government Finances from 1951 to 2008. We compute schools at the district level and that $70 \%$ of the increase in expenditures came in the form of capital outlays. 
the annualized real growth rates of expenditures on infrastructure for each of the six decades. The Census Bureau data contain different categories of infrastructure spending on roads, education, health, utilities, correction and judicial facilities. We focus on two categories, highways and higher education. The former includes data on the construction, maintenance, and operation of highways, streets, toll highways, bridges, tunnels, ferries, street lighting, and snow and ice removal. For this category, we use the capital outlays of direct expenditure on infrastructure, which take into account the construction of buildings, roads, purchase of equipment, as well as improvements of existing structures. The second item refers to operations of local public schools, construction of school buildings, and purchase of school buses. For both items, we compute annualized growth rates in real terms, by subtracting the inflation rate calculated from BEA data (by using the price index of state government investment goods from the US Economic Accounts; see Table 3.9.4. Price Indexes for Government Consumption Expenditures and Gross Investment, at http://www. bea.gov/) from the growth rate of nominal spending.

Table 1 provides some summary statistics for our main variables and Figures 3-4 provide a simplified graphic illustration of the data.

Table 1: Data Summary Statistics

\begin{tabular}{lcccccccc}
\hline \hline Variable & N & Mean & St.Dev. & Min. & $\mathbf{2 5 \%}$ & Med. & $\mathbf{7 5 \%}$ & Max. \\
\hline Overall Gini & 306 & 0.42 & 0.04 & 0.35 & 0.39 & 0.42 & 0.45 & 0.57 \\
Bottom 40\% Gini & 306 & 0.25 & 0.03 & 0.19 & 0.23 & 0.25 & 0.27 & 0.36 \\
Top 40\% Gini & 306 & 0.26 & 0.03 & 0.22 & 0.24 & 0.26 & 0.28 & 0.37 \\
Highways Growth Rate & 306 & 0.04 & 0.07 & -0.44 & 0.00 & 0.03 & 0.08 & 0.28 \\
Higher Edu. Growth Rate & 306 & 0.07 & 0.11 & -0.89 & 0.05 & 0.07 & 0.09 & 1.44 \\
\hline
\end{tabular}

van der Weide and Milanovic (2014) provide further description of the Gini data, which we draw the attention to. It is worth pointing out that there is a notable difference in state level government expenditures for highways and higher education. While Figure 4 reveals only a couple of points with negative growth rates for higher education spending, Figure 3 shows that in contrast it is much more common for US states to reduce real spending on highways. To support our observation that there is in fact a mismatch in the capital outlay for higher education and highways, we note that while Table 1 reports a larger standard deviation for higher education growth than for highways growth, it also shows that the $25 \%$ quantile is zero for highways growth but $5 \%$ for higher education spending. In other words, almost all states increased their spending on higher education in real terms, over the period 1950-2010. In contrast, many state budgets saw episodes with decreasing highways spending. In fact, negative real growth rates between $-5 \%$ and $-10 \%$ were not uncommon patterns. ${ }^{3}$ In Appendix 7.2, we report more summary statistics at the state level.

In addition to our data on growth rates of infrastructure spending, we also add four state-level controls that are potential determinants of income inequality and that have been used by van der Weide and Milanovic (2014). The first two relate to the fraction of household members that are either too young (under age 15) or too old (over 65) to work. The third is the education shortfall for individuals between 15 and 18, while the last measures the fraction of household members with at least four years in college. Like the Gini indices, those four controls are obtained from the IPUMS for 1960, 1970, 1980, 1990, 2000 and 2010.

\footnotetext{
${ }^{3}$ Alaska in the 1950-60 decade accounts for the most negative growth rates of highways and higher education, that is, $-43.9 \%$ and $-89.4 \%$ respectively. On the other hand, the growth rates of highways and higher education in the District of Columbia were $-24.4 \%$ and $144.1 \%$ respectively in the same decade.
} 
Figure 3: Highways Spending Growth Rate and Gini Indices
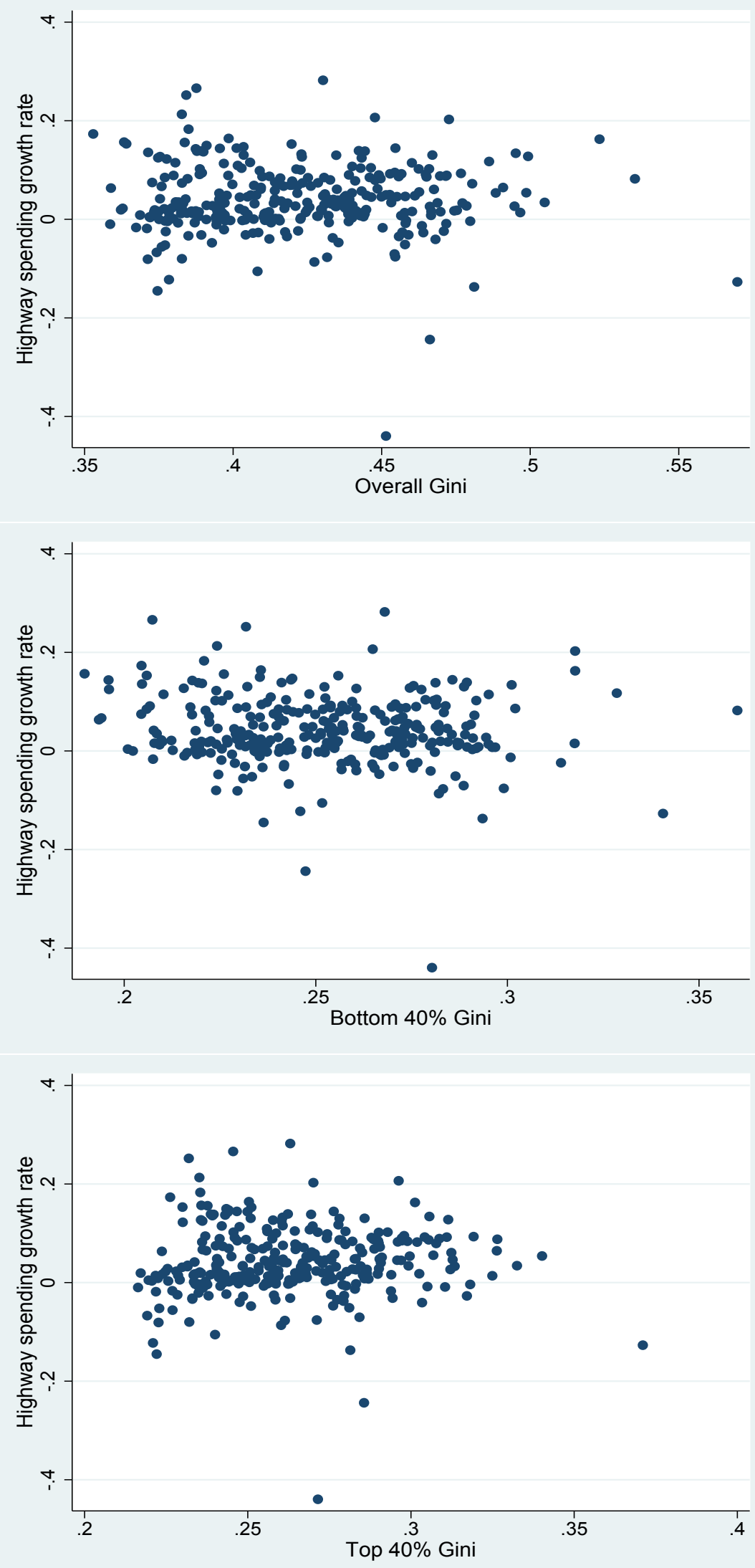
Figure 4: Higher Education Spending Growth Rate and Gini Indices
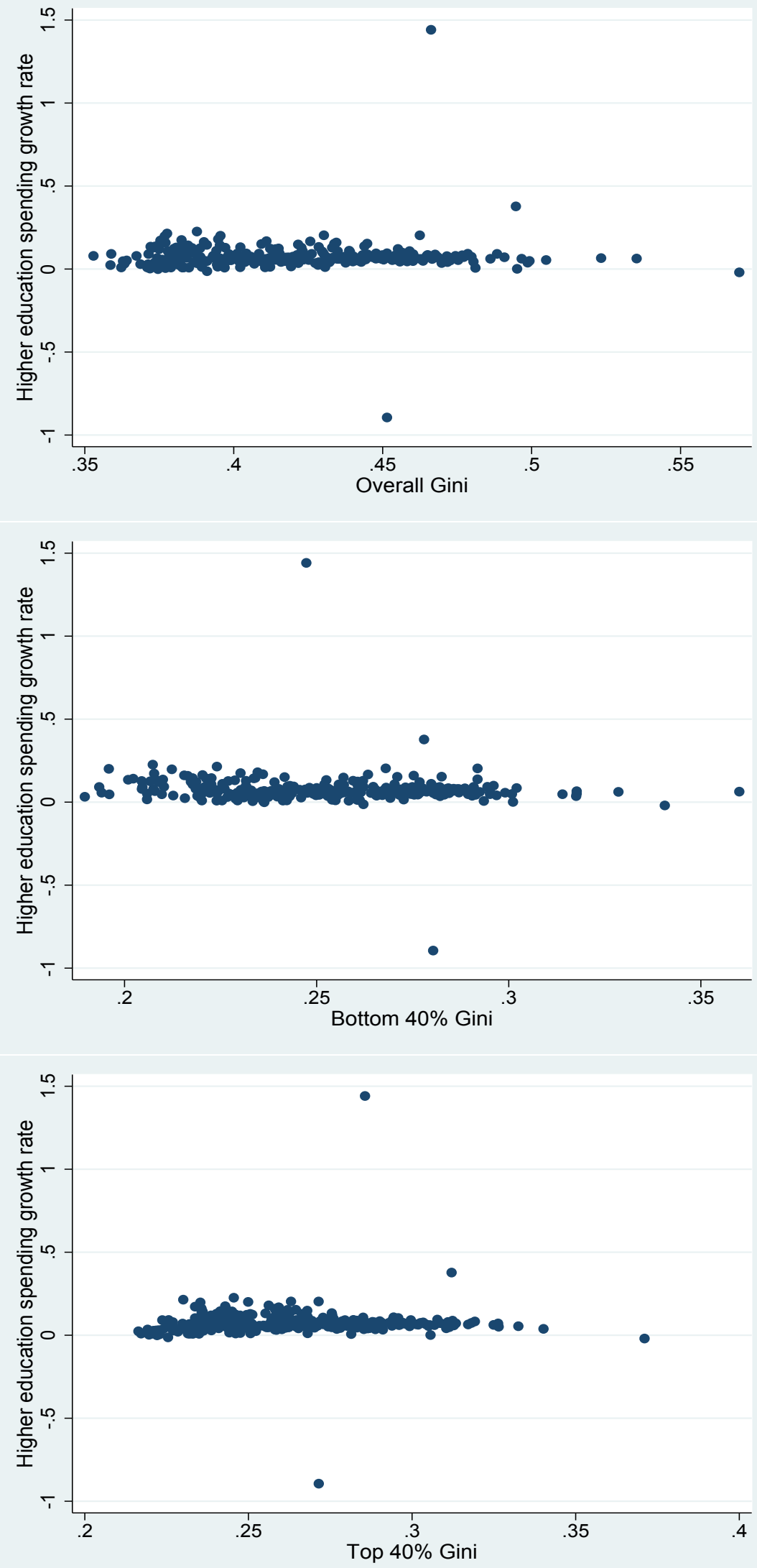
Our methodological approach involves carrying out a panel regression of overall Ginis, bottom Ginis and top Ginis in year $t$ on real growth rates in infrastructure spending over the decade prior to $t$, all at the state level, adding the four controls defined above, as well as year and state fixed-effects so as to limit endogeneity biases due to omitted variables. Our goal is to determine whether or not Ginis correlate with past infrastructure spending, and if they do, to determine what the direction of such a relationship would be. More formally, the panel regression is based on the following equation:

$$
\operatorname{Gini}_{i t}=\alpha \operatorname{InfraGrowth}_{i t}+\beta^{\prime} X_{i t}+\mathrm{FE}_{i}+\mathrm{FE}_{t}+\varepsilon_{i t} \text { for } t=1, \ldots, 6 \text { and } i=1, \ldots, 51
$$

where $t$ refers to a particular year (1960, 1970, 1980, 1990, 2000 or 2010) and $i$ refers to a particular state (from all US states and Washington D.C.). For example, Gini $i_{i t}$ is the Gini index for state $i$ in year $t$. Similarly, included in vector $X_{i t}$ are the four state-level controls that come from the IPUMS (that is, the proportions of household members that are under age 15 and over 65 , the education shortfall for individuals between 15 and 18, the fraction of household members with at least four years in college) for state $i$ and year $t$. The variable of interest to us is InfraGrowth $_{i t}$, which is the average annual growth rate of infrastructure spending on either highways or higher education over the decade preceding year $t$ in state $i$. The variable $\mathrm{FE}_{i}$ captures state fixed effects while $\mathrm{FE}_{t}$ captures time fixed effects - that is, the influence of aggregate trends. The residual term is $\varepsilon_{i t}$. In most tables, coefficients for year dummies - not reported - turn out to be statistically significant.

\section{A Causal Link From US State-Level Spending on Infras- tructure To Income Inequality?}

\subsection{Panel Regression Results}

The main results are presented in Tables 2 to 4 . Tables 2 and 3 examine the effects of highways and higher education separately, while Table 4 provides results with both variables included in equation (1). All three tables show that the overall Gini index correlates negatively with infrastructure spending, both for highways and for higher education. In other words, states which have financed high growth rates of spending on either highways or higher education - or both - over a decade turn out to experience lower inequality at the end of the decade. Also, all tables report positive coefficients for the four controls, which indicates that more inequality - especially at the bottom is observed. This is especially notable in states with a larger fraction of household members that are under age 15 or over 65 , with a larger education shortfall for individuals between 15 and 18 , or with a larger proportion of household members with at least four years in college.

Disaggregation of the Gini index between bottom Gini and top Gini in Tables 2 and 3 shows a larger effect of highways and higher education spending for bottom inequality than for top inequality. In addition, while coefficients on the four controls are not very different across both tables, the coefficients on highways and higher education do reveal variances: Tables 2 and 3 suggest an even stronger relationship between inequality and highways spending than between inequality and higher education spending. This result, as shown in Table 4, remains valid if both types of infrastructure are added as explanatory variables into equation (1), on top of our four controls and state and time fixed effects. The main insight is that inequality is much lower in states with strong highways spending growth, compared to states with strong higher education spending growth. One possible explanation is the observation, discussed above when commenting on Table 1, that many states have experienced episodes where highways spending has declined in real terms, whereas negative 
growth rates for higher education spending is very rare. Those episodes featured by a decline in highways spending have been associated with larger increases in inequality, compared to the ubiquitous episodes of decelerating but always positive growth of higher education spending.

The negative correlation that we document - between Ginis in year $t$ and growth rates of spending on infrastructure in the decade preceding year $t$ - arguably suggests a causal effect from growth in infrastructure spending to inequality. In other words, US states with high growth rates of spending on highways or higher education enjoy lower inequality a decade down the road. ${ }^{4}$ Causality, however, has been thought to be possibly running in the opposite direction, as suggested by the earlier literature on inequality and growth. The idea being put forward is that states with high inequality (especially bottom inequality) have lower growth rates of infrastructure spending, either because the richest segment of the income distribution opts out from the financing of infrastructure or because larger inequality triggers more transfers that crowd out infrastructure investments. In order to test that assumption, we have run regressions of growth rates on infrastructure spending on lagged Ginis, together with state and year fixed effects. Unreported results show that the obtained coefficients of lagged Ginis are not significant, even at 10\%. Our data provide no evidence of past inequality having an adverse effect on future infrastructure spending. In contrast, we do find that past infrastructure spending is associated with less inequality at the end of the decade. Our results therefore support the argument that investments in infrastructure contribute to enlarge geographical mobility and hence to reduce inequality.

As robustness checks, we also report additional results in Appendix 7.1. Most importantly, Tables 5-7 show that our results are essentially unchanged if we add in our regressions the levels of infrastructure spending (averaged over decades) on top of the growth rates: the coefficients on levels are very small (smaller than $10^{-6}$ ) while the coefficients on growth rates are very close to those in Tables 2 to 4 and turn out to be more precisely estimated. This clearly indicates that, according to the data we are using, inequality is affected by the growth rate - not the level - of spending on infrastructure, both for highways and higher education. Second, Appendix 7.1 show results from regressions with state fixed effects but no year fixed effects. From Tables 8-10, we conclude that highways and higher education spending growth only affects bottom inequality, with a negative coefficient, when year fixed effects are dropped. In addition, the resulting $R^{2} \mathrm{~s}$ are lower when year fixed effects are not added. We also report in Appendix 7.1 the results from standard OLS regressions in Tables 11-13, which show that coefficients for highways or higher education come with a positive sign now, whenever significant, suggesting that only aggregate time-series trends are captured. Another indication that standard OLS regressions without any fixed effects are misleading are the poor $R^{2} \mathrm{~s}$, compared to the outcome with state and year fixed effects. Such a robustness exercise, we conclude, clearly supports our main results in Tables 2 to 4: with both state and year fixed effects, infrastructure spending on highways and higher education correlates negatively with income inequality in the US from 1950 to $2010 .^{5}$

The panel regression results that we report are far from being economically insignificant. Table 4 implies that a one standard deviation increase in the growth rate of spending on highways and higher education would be associated with a fall in the overall Gini of about $(0.07 \times-0.027+0.11 \times-.012=)$

\footnotetext{
${ }^{4}$ Our interpretation in terms of causality from infrastructure to inequality is reinforced by the fact that lagged growth rates - that is, from years $t-20$ to $t-10$ - of infrastructure spending turn out to be also significant, implying dynamic effects of infrastructure on inequality that last longer than a decade, especially for spending on highways.

${ }^{5}$ We have also run our panel regressions excluding Alaska and DC, which account for all state-year pairs that might appear as "outliers" in Figures 3-4 as already remarked. Our main results turn out to be robust to that change. For example, coefficients for highways and higher education in the regressions of bottom Gini become larger when Alaska and DC are excluded.
} 
Table 2: Effect of Highways Spending on Inequality - State \& Year Fixed Effects

\begin{tabular}{|c|c|c|c|}
\hline & $(1)$ & $(2)$ & $(3)$ \\
\hline & Total Gini & Bottom Gini & Top Gini \\
\hline \multirow[t]{2}{*}{ Highways } & $-0.031^{* * *}$ & $-0.030^{* *}$ & $-0.020^{* * *}$ \\
\hline & $(0.008)$ & $(0.011)$ & $(0.006)$ \\
\hline \multirow[t]{2}{*}{ Under Age 15} & $0.759^{* * *}$ & $0.439^{* * *}$ & $0.488^{* * *}$ \\
\hline & $(0.115)$ & $(0.100)$ & $(0.076)$ \\
\hline \multirow[t]{2}{*}{ Over Age 65} & $0.428^{* * *}$ & $0.370^{* * *}$ & $0.249^{* * *}$ \\
\hline & $(0.113)$ & $(0.114)$ & $(0.087)$ \\
\hline \multirow[t]{2}{*}{ Education Shortfall } & $0.044^{* * *}$ & $0.054^{* * *}$ & 0.012 \\
\hline & $(0.016)$ & $(0.017)$ & $(0.008)$ \\
\hline \multirow[t]{2}{*}{ College } & $0.396^{* * *}$ & $0.519^{* * *}$ & $0.137^{* *}$ \\
\hline & $(0.082)$ & $(0.086)$ & $(0.058)$ \\
\hline \multirow[t]{2}{*}{ Constant } & 0.067 & -0.000 & $0.052^{*}$ \\
\hline & $(0.043)$ & $(0.037)$ & $(0.030)$ \\
\hline Observations & 306 & 306 & 306 \\
\hline$R^{2}$ & 0.823 & 0.633 & 0.896 \\
\hline State fixed effects & Yes & Yes & Yes \\
\hline Time fixed effects & Yes & Yes & Yes \\
\hline
\end{tabular}

Robust standard errors in parentheses.

${ }^{*} p<0.10,{ }^{* *} p<0.05,{ }^{* * *} p<0.01$

-0.003 on average. Such a reduction in the overall Gini over the next 10 years would undo the increase observed between 2000 to 2010, from 0.461 to 0.464 . Of course, this implies sizeable increases in spending growth rates, of about 11pp for higher education and $7 \mathrm{pp}$ for highways, but such magnitudes have not been unfrequent over the last 60 years. For example, the state of Connecticut increased its growth rate on higher education spending from $3.2 \%$ in $1950-60$ to $13.6 \%$ in 1960 70. The same state increased its growth rate on highways spending from $-5.6 \%$ in $1970-80$ to an astonishingly high $16.4 \%$ in 1980-90, hence an increase of about 20pp. Unfortunately, Connecticut has since experienced much smaller growth rates of higher education spending (between $2.8 \%$ and $7.7 \%$ since 1970) and even negative growth rates for highways spending (between $-4.1 \%$ and $-2.7 \%$ since 1990). This state belonged in 2008 to the top $25 \%$ quantile of the US states inequality distribution. Similarly, from Table 4 we derive that increasing highways and higher education spending growth rate by one standard deviation would go hand in hand with a fall in the bottom Gini of about $(0.07 \times-0.026+0.11 \times-.016=)-0.0036$ on average. Such a fall in the bottom Gini index would more than undo its increase observed between 1990 and 2000, when it went from 0.260 to 0.262 . In other words, a one standard deviation increase in the real growth rate of spending on highways and higher education would reduce the bottom Gini by $20 \%$ more than the overall Gini.

As noticed before, the US Census Bureau data on infrastructure spending contains several categories. We have estimated equation (1) using growth rates of spending on other types of infrastructure. While the resulting infrastructure coefficients are not significant, we still think it is informative 
Table 3: Effect of Higher Education Spending on Inequality - State \& Year Fixed Effects

\begin{tabular}{lccc}
\hline \hline & $(1)$ & $(2)$ & $(3)$ \\
& Total Gini & Bottom Gini & Top Gini \\
\hline Higher Education & $-0.016^{* *}$ & $-0.019^{* * *}$ & $-0.015^{*}$ \\
& $(0.008)$ & $(0.004)$ & $(0.007)$ \\
Under Age 15 & $0.743^{* * *}$ & $0.422^{* * *}$ & $0.475^{* * *}$ \\
& $(0.114)$ & $(0.093)$ & $(0.076)$ \\
Over Age 65 & $0.386^{* * *}$ & $0.322^{* * *}$ & $0.213^{* *}$ \\
& $(0.117)$ & $(0.114)$ & $(0.090)$ \\
Education Shortfall & $0.043^{* * *}$ & $0.052^{* * *}$ & 0.011 \\
& $(0.016)$ & $(0.018)$ & $(0.008)$ \\
College & & & \\
& $0.355^{* * *}$ & $0.474^{* * *}$ & $0.104^{*}$ \\
Constant & $(0.083)$ & $(0.079)$ & $(0.061)$ \\
& & & \\
State fixed effects & Yes & Yes & Yes \\
\hline \hline & $0.077^{*}$ & 0.012 & $0.062^{*}$ \\
\hline Observations & $(0.045)$ & $(0.036)$ & $(0.031)$ \\
\hline
\end{tabular}

Robust standard errors in parentheses.

${ }^{*} p<0.10,{ }^{* *} p<0.05,{ }^{* * *} p<0.01$

to point out that those items correlate negatively with inequality. The growth rates of capital outlays on judicial and legal, public building, and total education (including elementary and secondary) correlate negatively with overall, bottom and top Ginis. The growth rate of capital outlays on air transportation also correlates negatively with inequality, but only for overall and bottom Ginis. Finally, the growth rates of capital outlays on hospitals and health are negatively related to the bottom Gini. ${ }^{6}$

Although the results presented in this paper help us to better understand the relationship between infrastructure and inequality, they are not void of shortfalls. There are several limitations to the data that we have employed. Waves of income survey are 10 years apart and the size of the micro-census varies between $1 \%$ and $5 \%$ depending on the survey period. While the overall size of the dataset is an advantage, the variation in size over time may pose concerns. In addition, our data on infrastructure do not allow us to disaggregate construction, maintenance and improvement expenditures. While this data set enables us to access information on state expenditures on infrastructure, it does not provide information about the quality of public goods. Finally, while we focus on spending at the state level, it would be interesting to look at expenditures on infrastructure at a more local level, such as in counties or in Metropolitan Statistical Areas.

Even though it may not come as a surprise that our results show that inequality correlates

${ }^{6}$ Unfortunately, Census Bureau data on water, electric, gas, and transit utilities are available only since 1977. With fewer data points, a similar analysis is still feasible but is left for future research. 
Table 4: Effect of Higher Education and Highways on Inequality - State \& Year Fixed Effects

(1)

(2)

(3)

\begin{tabular}{lccc} 
& Total Gini & Bottom Gini & Top Gini \\
\hline Higher Education & $-0.012^{* * *}$ & $-0.016^{* *}$ & $-0.013^{* * *}$ \\
& $(0.004)$ & $(0.008)$ & $(0.004)$ \\
Highways & $-0.027^{* *}$ & $-0.026^{*}$ & $-0.017^{* *}$ \\
& $(0.010)$ & $(0.014)$ & $(0.007)$ \\
Under Age 15 & $0.751^{* * *}$ & $0.429^{* * *}$ & $0.480^{* * *}$ \\
& $(0.111)$ & $(0.091)$ & $(0.073)$ \\
& & & \\
Over Age 65 & $0.402^{* * *}$ & $0.337^{* * *}$ & $0.222^{* *}$ \\
& $(0.117)$ & $(0.112)$ & $(0.090)$ \\
Education Shortfall & $0.042^{* * *}$ & $0.051^{* * *}$ & 0.010 \\
& $(0.015)$ & $(0.018)$ & $(0.007)$ \\
College & & & \\
& $0.374^{* * *}$ & $0.491^{* * *}$ & $0.115^{*}$ \\
Constant & $(0.086)$ & $(0.083)$ & $(0.062)$ \\
& & & \\
& $0.076^{*}$ & 0.010 & $0.061^{* *}$ \\
Observations & $(0.044)$ & $(0.035)$ & $(0.030)$ \\
$R^{2}$ & 306 & 306 & 306 \\
State fixed effects & 0.825 & 0.638 & 0.899 \\
Time fixed effects & Yes & Yes & Yes \\
\hline \hline
\end{tabular}

Robust standard errors in parentheses.

${ }^{*} p<0.10,{ }^{* *} p<0.05,{ }^{* * *} p<0.01$

negatively with higher education, the fact that it still correlates negatively but more signficantly with highways spending deserves more attention. Such a pattern is in accordance with the notion that transportation infrastructure improves social mobility because of better access to a large number of employment opportunities and schools. For example, Chetty and Hendren (2015) assert that the geographical location, more specifically neighborhoods in the US where children reside all the way up to early adulthood (to age 20), has a clear impact on social mobility. This could include access later in life to admission to higher educational institutions, employment opportunities, and particularly to filling skilled labor positions. Poor neighborhoods are often characterized by poor quality of teaching in schools, as well as poor transportation access. Approximately 50 percent of the variation in intergenerational mobility in the US, based on their empirical research, is attributed to the causal effects from the exposure of children to residing in a given neighborhood over the first two decades of their lives. While their research does not make any sort of clear linkage to the impact of infrastructure (highways and other means of surface transportation) in neighborhoods within the US on social mobility, implicitly this factor cannot be overlooked. While our results do not establish causal link between infrastructure expenditure and social mobility, they do not contradict the view that infrastructure spending may help reduce inequality through enhancing social mobility. ${ }^{7}$

\footnotetext{
${ }^{7} \mathrm{~A}$ recent ruling by State Superior Court judge Moukawsher in Connecticut highlights the urgent need for the
} 


\subsection{Regional Implications: A Counterfactual Exercise}

Figure 5: Counterfactual Bottom Gini Variations when States are Given the Median Highways Spending Growth Rate in the 2000s. States with Negative (Positive) Gini Variation in Red (Blue). Darker Colors Indicate Larger Variations (See Appendix 7.3 for Exact Magnitudes).

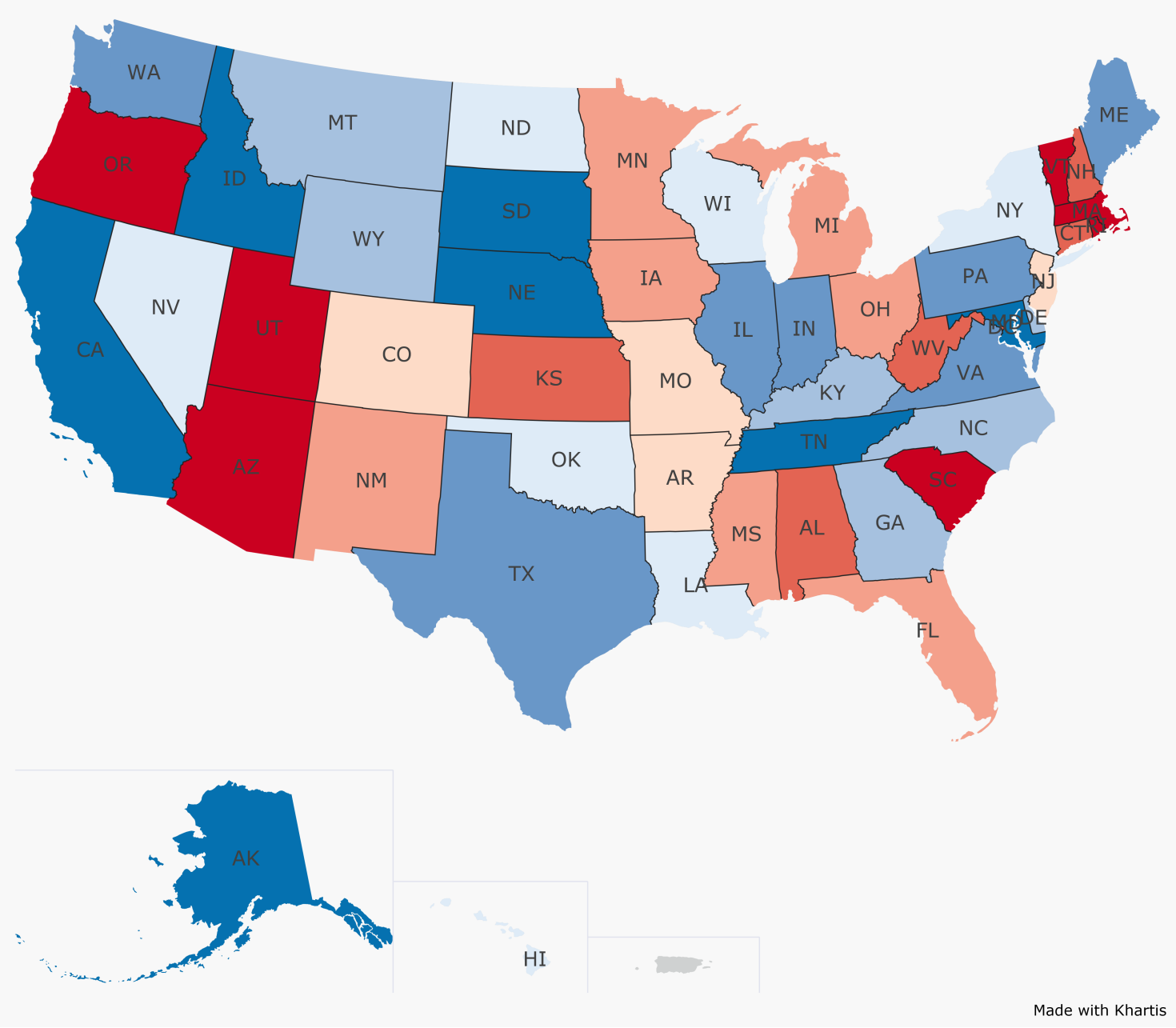

In this section we would like to stress some regional implications of our empirical results. More specifically, a counterfactual exercise has enabled us to determine which states may deemed to be losers and winners in terms of bottom income inequality, because of infrastructure spending growth from 2000 to 2010. We undertake this exercise in two stages. We first group states into four quartiles, based on the distribution of infrastructure growth rates over the decade mentioned above, both for higher education as well as for highways. The idea here is that we are willing to group states with similar abilities to fund infrastructure spending. We compute the median infrastructure growth rates for each group and then subtract the actual growth rate from 2000 to 2010. Of course, some

state to entirely rethink its policy on school funding, which is thought not to be driven by rational motives. See http://www.nytimes.com/2016/09/12/nyregion/in-connecticut-a-wealth-gap-divides-neighboring-schools . html?mwrsm=Email. 
Figure 6: Counterfactual Bottom Gini Variations when States are Given the Median Higher Education Spending Growth Rate in the 2000s. States with Negative (Positive) Gini Variation in Red (Blue). Darker Colors Indicate Larger Variations (See Appendix 7.3 for Exact Magnitudes).

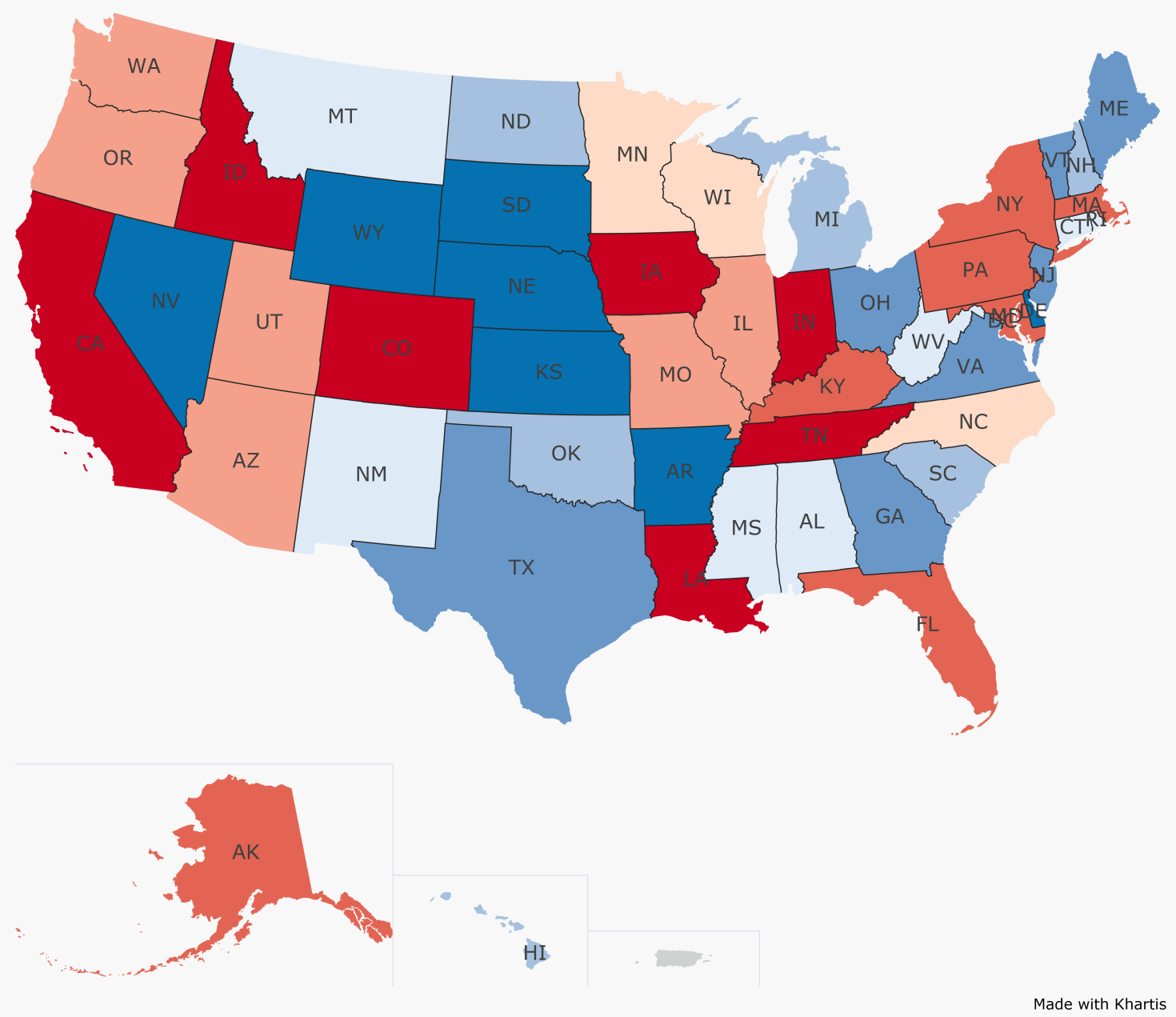

states end up with a positive difference because they underinvested in infrastructure, compared to the median state in their group. In the second step, we multiply the counterfactual growth rate deficit/surplus by the regression coefficient of bottom Ginis on highways and higher education, respectively from Tables 2-3. The outcome of this procedure is that we get counterfactual bottom Gini variations for each state in 2010, which gives a sense of the extent to which inequality would have been lower or higher, ceteris paribus, had the state experienced the median growth rate of infrastructure spending. The resulting counterfactual bottom Gini variations are reported in two maps, in Figure 5 for highways and Figure 6 for higher education. More details about the grouping in quartiles are reported in Appendix 7.3, for each state in each of the four quartiles. To put it differently, in Figures 5-6, those states with negative variations in their bottom Gini - represented in red - would have enjoyed lower bottom inequality had they invested like the median state in their quartile, while above-median states with positive variations - represented in blue - would have 
seen higher bottom inequality materialize had they invested like the median state in their group. The magnitudes in Figures 5-6 are not trivial. For example, the inequality losses for Massachusetts and Rhode Island due to underinvestment in highways - see Figure 5 - account for about $5 \%$ of the increase in bottom inequality observed from 2000 to 2010. In fact, if Massachusetts and Rhode Island had invested in highways as California in that decade, their level of bottom Gini in 2010 would have been reduced by respectively $25 \%$ and $23 \%$.

There are several lessons that one can draw from Figures 5-6 (and Figures 10 to 13 in Appendix 7.3). First, the counterfactual variations in bottom inequality due to highways over/underinvestment are larger than those related to higher education. This observed pattern is in line with what was noted earlier that both that highways growth is more volatile than higher education and that regression coefficients of Ginis on infrastructure growth rate are larger for highways than for higher education. Second, for both items, positive and negative variations in quartiles 1 and 4 exceed those of quartiles 2 and 3. For example, in Figure 5 and in red, Rhode Island - which belongs to the first quartile - would have gained three times more than New Hampshire (second quartile), in terms of reducing bottom inequality, if both states had invested at the median level from 2000 to 2010. On the winner side (in blue), California (fourth quartile) has avoided a rise in bottom inequality twice the size of Idaho (third quartile), compared to what would have happened had both invested like the median state within their respective quartile. Similarly, variations in inequality due to higher education growth deficit/surplus are larger in the first and fourth quartiles than in quartiles 2 and 3. An important limitation is that we are not able to identify the very reason why discrepancies between quartiles arise. This may partly be due to not fully understanding the various determinants of infrastructure growth. Obviously, credit constraints at the state level could explain why underinvesting is more costly in terms of inequality in the lowest quartile. Moreover, increased credit access does not garantee increased spending on infrastructure. Political economy reasons, including short-termism, or lobbying by firms for government subsidies could also lessen the will to invest in infrastructure. A third factor could also be the limited awareness, resulting in part from the lack of documented and convincing evidence, that neglecting infrastructure investment can exacerbate inequality. Lastly, inequality losses due to underinvestment relative to the median state are in the lowest 3 quartiles typically larger than inequality gains in above-median states. This is true for both highways and higher education. This suggests that there is some asymmetry in the sense that infrastructure underinvestment (again relative to the median) is more costly in terms of inequality when the level of infrastructure growth rate is lower, except in the highest quartile.

\section{Alternative Sources to Public Funding for Infrastructure}

Our empirical results suggest that increasing infrastructure investments can be enormously effective as a strategic policy measure to mitigate inequality of various forms, but it is important to recognize that they do not guarantee that this outcome will automatically occur. India's major infrastructure initiative known as the "Golden Quadrilateral Network", for example, which sought to connect the four regions of the country with a modern highways system, has had negligible or no impact on reducing inequality. The main users of this transportation network are large firms to address supply chain and logistical challenges. The other main beneficiaries have been those individuals who make up the top decile of the population in per capita income terms. The bottom decile has experienced no change. Infrastructure investments by development banks and international development organizations in Palestine has produced similar adverse results (Salamanca, 2014). Besides 
the effectiveness of infrastructure to generate growth and reduce inequality, a major concern is how to fund new projects. In this section, we review key proposals that help identify solutions to this problem.

\subsection{Investing in Infrastructure Through Public-Private Partnerships}

A careful review of the economics literature on PPP's shows is that efficiency is enhanced through structuring an infrastructure contract by bundling construction and service provisions to a single contractor. ${ }^{8}$ How so? A single contractor has a stronger incentive to undertake construction projects that keep future operating costs as low as possible. This would however not be the case if construction and service provisions were divided and allocated to two separate contractors. One drawback of structuring the PPP by bundling construction and operation, however, is that this generally involves a very long-term contract, lasting over 25 to 40 years. Moreover, under such a contract the operator faces significant risk, both during the construction phase and in the operating phase. It is generally not efficient to expose the operator to the entire risk of the project. To the extent that the government is better able to absorb risk it makes sense to provide some insurance to the PPP operator, even if this comes at the expense of incentives to deliver services.

The economics literature has devoted inadequate attention to the fundamental question of how to structure financing of investments under PPPs, how much should come from private sources and in what form and how much should come from public sources. An equally striking observation is that almost all the economics literature on PPPs frames the contract as a bilateral contract between a private provider and a government agency. A third party can play an important role to monitor and also to improve the efficiency of contract enforcement. In most developing countries the obvious third party is a multilateral development bank, which can play not only a key monitoring role of both the service provider and the government agency, but also a fundamental role in structuring financing efficiently and providing optimal insurance or guarantees to private investors in PPPs. Structuring financing of PPPs is not just a technical question; it is what supports the delicate balance between the interests and comparative advantages of the different partners in the PPP. It not just a question of optimally allocating the different risks involved in an infrastructure project, but also a question of setting up the right governance structure to ensure the sustainability of the project. Given the public goods nature of most PPP projects a fundamental difficulty is to find a way to internalize the positive externalities produced by the project without excessively excluding all the potential beneficiaries of the project.

Development banks and can play a critical role in fostering infrastructure investment especially by alleviating governments' financial constraints and risk sharing.For that to happen, development banks and foundations would need to increase the leverage their own capital tapping into available vast pools of long-term savings or allow for greater and innovative co-financing of projects including through allowing private investors. The involvement of development banks in PPP's can help scale up global infrastructure investment through alleviating governments' financial constraints. Most PPPs are too small in scale. Considering the breadth and depth of development banks' expertise in infrastructure, development banks can facilitate the origination and the development of large scale projects and reduce political risk associated with the project. For that development banks need not only respond to the needs of governments around the world but also follow to the leads of private investors whom may also help identify viable projects. Considering the opportunity presented by

\footnotetext{
${ }^{8}$ Much of this section is drawn from a forthcoming paper by Arezki, Bolton, Peters, Samama, and Stiglitz, 2016.
} 
the large pools of long-term savings, the provision of expertise in origination, guarantees and an improved institutional framework by development banks can be a catalyst for more private sector involvement and in turn scaling up the volume of PPPs. The scaling up on infrastructure can lead to the densification of networks both domestically and regionally. Indeed, the degree of "bankability" of individual infrastructure projects rests on the whole infrastructure network. Development banks can help governments and private actors internalize those externalities and further alleviate financial constraints.

\subsection{Multilateral and Regional Infrastructure Platforms}

Before we describe the various existing infrastructure investment platforms, it is useful to discuss in broad terms the mandate and role played by multilateral development banks (MDBs). Various initiatives to promote infrastructure have been pursued by organizations such as the Asian Infrastructure Investment Bank (AIIB), European Bank for Reconstruction and Development (EBRD), New Development Bank (NDB), the World Bank and others (see Figure 7 for existing models, as described by Gutman et al., 2015). The Global Infrastructure Facility (GIF) under the World Bank became operational in April 2015, and the AIIB is leading the charge in developing an infrastructure investment platform in the Asia-Pacific Region. Especially the AIIB and NDB were founded on an understanding that the old model characterizing the WB and other multilateral institutions might not be fully appropriate for the 21st century. The NDB, for instance, focused on creating special investment funds, which would invest in a particular range of investment projects, with a particular risk profile, attractive to particular classes of investors. It serves an important function by engaging with special investment funds, bringing together an array of potential investors, from SWFs to pension funds, and even high net worth individual investors. The NDB employs modern financial techniques to provide an array of investment products - using structured finance in a responsible way to allocate risk, and by using securitization to pool risks. The governance structure within the mentioned different funds is generally regarded as being adaptable and responsive to the concerns of the investors (Peters, 2017).

In sum, there is growing recognition globally that development banks can play an important role in facilitating the preparation and financing of infrastructure projects by private long-term investors. A number of infrastructure platform initiatives have been launched very recently, most of them still at a prototype development stage. These platforms are all different attempts to tap into the vast pool of global long-term savings by better meeting long-term investor needs to attract them to infrastructure assets and by relaxing operating and governance constraints traditional development banks have been facing.

\subsection{Corporate Tax Revenues from Repatriated Profits}

New large sources of funding for infrastructure are required, beyond those linked to sovereign wealth funds, pension funds, regional development banks and by institutional investors. The world needs to increase its investment in infrastructure by nearly 60 percent until 2030. To reach those aggregate targets, investment in infrastructure will have to increase from $\$ 36$ tr over the past 18 years to $\$ 57$ tr over the next 18 years. One strategy certainly worthy of consideration is to earmark corporate tax revenues on repatriated profits earned by foreign multinational in developing countries, and also in mature markets, to finance infrastructure development in the host country. This amount could be sizeable: The Securities and Exchange Commission filings from the 500 largest American 
Figure 7: Development Bank Investment Platforms for Potential Infrastructure Investments

\begin{tabular}{|c|c|c|c|c|c|}
\hline & EIB & EBRD & WB & AIIB & NDB \\
\hline $\begin{array}{l}\text { Official } \\
\text { purpose }\end{array}$ & $\begin{array}{l}\text { Bring about } \\
\text { European } \\
\text { integration and } \\
\text { social cohesion }\end{array}$ & $\begin{array}{l}\text { Using investment as } \\
\text { a tool to help build } \\
\text { market economies }\end{array}$ & $\begin{array}{l}\text { Reduction of } \\
\text { worldwide poverty }\end{array}$ & $\begin{array}{l}\text { Provide finance to } \\
\text { infrastructure } \\
\text { projects in the Asia } \\
\text { Pacific region }\end{array}$ & $\begin{array}{l}\text { Mobilize resources for } \\
\text { infrastructure and } \\
\text { sustainable development } \\
\text { in BRICS and other } \\
\text { emerging economies }\end{array}$ \\
\hline Shareholders & EU member states & $\begin{array}{l}64 \text { countries and } 2 \\
\text { EU institutions. } \\
\text { USA is the largest } \\
\text { shareholder }\end{array}$ & $\begin{array}{l}188 \text { member } \\
\text { countries. Top } 5 \\
\text { countries by voting } \\
\text { power are USA, } \\
\text { Japan, China, } \\
\text { Germany, and } \\
\text { France. Thus, } \\
\text { dominated by } \\
\text { American, European } \\
\text { and Japanese } \\
\text { interests }\end{array}$ & $\begin{array}{l}22 \text { Asian countries. } \\
\text { China holds the } \\
\text { major stake }\end{array}$ & $\begin{array}{l}\text { The "BRICS" countries: } \\
\text { Brazil, Russia, India, } \\
\text { China, and South Africa }\end{array}$ \\
\hline $\begin{array}{l}\text { Inception and } \\
\text { initial mission }\end{array}$ & $\begin{array}{l}\text { Nonprofit long- } \\
\text { term lending } \\
\text { institution } \\
\text { established in } 1958 \\
\text { under the Treaty of } \\
\text { Rome }\end{array}$ & $\begin{array}{l}\text { Founded in April } \\
1991 \text { during the } \\
\text { dissolution of the } \\
\text { Soviet Union. } \\
\text { Support countries } \\
\text { of the former } \\
\text { Eastern Bloc in the } \\
\text { process of } \\
\text { establishing their } \\
\text { private sectors }\end{array}$ & $\begin{array}{l}\text { One of the key } \\
\text { Bretton Woods } \\
\text { institutions founded } \\
\text { in } 1944 \text { to increase } \\
\text { cooperation on an } \\
\text { international scale }\end{array}$ & $\begin{array}{l}\text { Founded in } 2014 \text { as } \\
\text { China was } \\
\text { frustrated with the } \\
\text { slow pace of } \\
\text { reforms and } \\
\text { governance of the } \\
\text { American, } \\
\text { European and } \\
\text { Japanese members }\end{array}$ & $\begin{array}{l}\text { The idea for setting up } \\
\text { the bank was first } \\
\text { proposed in } 2012 \text { at the } \\
4^{\text {th }} \text { BRICS summit; The } \\
\text { agreement on provision } \\
\text { of legal basis was } \\
\text { signed in July } 2014 \text {, and } \\
\text { was entered into force in } \\
\text { July } 2015 \text {. The NDB } \\
\text { was formerly known as } \\
\text { the BRICS } \\
\text { Development Bank }\end{array}$ \\
\hline
\end{tabular}

corporations, estimated that these companies hold at least $\$ 2.1 \mathrm{tr}$ in accumulated profits offshore. This could generate $\$ 620 \mathrm{bn}$ in US taxes if they repatriated the funds (cf http://www. uspirg.org/ sites/pirg/files/reports/USP\%20ShellGames\%200ct15\%201.3.pdf).

Tax revenues from repatriated profits could be earmarked for specific infrastructure investments while companies repatriating profits could be minority investors in such long-term infrastructure projects. If even half of the $\$ 2.1$ tr were repatriated, the resulting $\$ 310 \mathrm{bn}$ could go a long way in rebuilding the crumbling US infrastructure as well as investing in infrastructure in developing countries. Sources for infrastructure funding within the euro-zone and in developing countries could be generated similarly. Developing country governments could also incentivize up-front tax payments on estimated corporate profits. Thus far, most multinational corporations have been making use of public infrastructure at zero cost. Creating partnerships between corporate investors and host governments could provide urgently needed funds to finance infrastructure. Due to the recent media attention generated by public scandals such as the Swiss Leaks, Luxembourg Leaks, and more recently, the Panama Papers, and the ensuing mandate by the G20 to the OECD to reform international tax standards, MNEs are under heavy scrutiny to provide full disclosure on earnings, transfer pricing, profits, adhere to regulations and comply with local and international laws. The positive publicity derived from corporate social responsibility by investing in infrastructure in poor countries could substantially compensate MNEs for the diversion of tax payments to an infrastructure fund. In addition, this option would allow private corporations to use infrastructure investments as an important savings vehicle.

To avert risk of corrupt host country governments usurping the funds, regional development banks could guide such funds via an infrastructure investment platform. RDBs could play a more active role 
to monitor, enhance transparency, improve governance, serve as guarantor in the event of default and to fulfill an advisory function in such areas as project preparation in private, public partnerships in infrastructure. The European Investment Bank and the World Bank's Global Infrastructure Facility can serve as useful examples, in addition to the newly created Asian Infrastructure Investment Bank, led by China. Skeptics to this novel approach of generating financial resources through new tax policy measures would argue that it would be operationally non-viable to get global MNEs to finance infrastructure investments as a more palatable way to reduce corporate tax evasion and tax avoidance. Paradoxically, most policy makers and leading economists would be fully in favor of carbon tax as an important instrument to control global climate change, in spite of the laudable achievement of the signing of the Paris Global Climate Change Accord by G20 countries in 2016.

\section{Conclusion}

The state of US infrastructure is in urgent need of maintenance and upgrading. In view of the large empirical literature supporting the view that investments in infrastructure are key to ensure high levels of standards of living and economic growth, large-scale plans to enhance infrastructure should be given high priority. Our empirical analysis using US state-level data from 1950 to 2010 shows, more fundamentally, that future infrastructure investments, apart from stimulating growth, can potentially also contribute to lower income inequality. While we acknowledge that there are certain limitations to our data and analyses, we still hope that this paper offers a first step to better understand the relationship between infrastructure and inequality. It is beyond the scope of this paper to address the issue of causality more directly, for example by employing techniques such as using instrumental variables. However, preliminary results using inequality data set up by Frank (2009), based on annual state-level tax data, coincide with those presented in this paper. This suggests that a potentially fruitful way forward is to experiment with the instrument used by Aghion et al. (2009), which relies on data about decisions made by the US Senate and House appropriation committees (see also Cohen et al. , 2011). Our analyses could also potentially be extended to other data-rich countries from the European Union, Japan, Australia, and to other dimensions of inequality, such as wealth, consumption and also subjective well-being. Perhaps at first glance one expects developing countries to be less amenable to similar panel regressions, due to lack of reliable data. It remains to be seen, however, whether poverty indices and other aspects of inequality, such as limited access to health care, that are increasingly being measured in the South, could also be relied upon to assess the benefits and costs of infrastructure that are strongly needed there. We argue that escalating migration flows are also closely linked to infrastructure, both in relation to the fact that public goods are abundant in the North and lacking in the South. ${ }^{9}$

In view of the many obstacles to generate financial resources needed for infrastructure, especially in the current context of the most recent global economic crisis, where many countries continue to face high levels of government deficit and public debt, this paper puts forward various financial and policy innovations. Such innovations, as those involving the redirection of corporate tax revenues from multinational companies towards infrastructure spending, PPPs, augmented by greater involvement of multilateral development banks (MDBs) and global investment platforms that match long-term investors with long-term infrastructure projects, are going to need further refinement.

\footnotetext{
${ }^{9}$ See Peters and Pintus (2016) for a proposal in European context.
} 


\section{References}

[1] Aghion, P. and P. Bolton (1992). Distribution and Growth in Models of Imperfect Capital Markets. European Economic Review, 36: 603-611.

[2] Aghion, P. and P. Bolton (1997). A Theory of Trickle-Down Growth and Development. Review of Economic Studies, 64: 151-172.

[3] Aghion P, L. Boustan, C. Hoxby, and J. Vandenbussche (2009). The Causal Impact of Education on Economic Growth: Evidence from U.S. Mimeo Harvard University.

[4] Arezki, R., P. Bolton, S. Peters, and F. Samama (2014). Sovereign Wealth Funds and LongTerm Investments: a Proposal for a Global Infrastructure Investment Platform (GIIP), working paper, Bellagio.

[5] Arezki, R., P. Bolton, S. Peters, F. Samama, and J. Stiglitz (2016). From Global Savings Glut to Financing Infrastructure: the Advent of Investment Platforms. Forthcoming in Economic Policy.

[6] Aschauer D. (1989). Does Public Capital Crowd out Private Capital? Journal of Monetary Economics, 24: 171-188.

[7] Atkinson, A.B. (1997). Bringing Income Distribution in From the Cold. Economic Journal, 107: 297-321.

[8] Atkinson, A., F. Bourguignon, Eds. (2015). Handbook of Income Distribution. Elsevier.

[9] Bahety, G. Giesing, Y. Kayihan, E. Lima, F. Oesche, T and Xue, Q. (2012). The Causal Relationship Between Inequality and Growth: Literature Review. OECD.

[10] Bajar, S. and M. Rajeev (2015). The Impact of Infrastructure Provisioning on Inequality: Evidence from India. Working Paper Number 35, July 2015. The ILO, Global Labour University.

[11] Banerjee, A. and A. Newman (1993). Occupational Choice and the Process of Development. Journal of Political Economy, 101: 274-298.

[12] Becker, G. S. (1968). Crime and Punishment: An Economic Approach. Journal of Political Economy, 76: 169-217.

[13] Bénabou, R. (1996). Inequality and Growth, in Bernanke, B., and J. Rotemberg (Eds.), NBER Macroeconomics Annual.

[14] Berg, A., P. Loungani, and J. Ostry (2017). Inequality: Causes, Consequences, and Cures. Columbia University Press, forthcoming.

[15] Bom, P.R.D., and J. Ligthart (2008). How Productive is Public Capital? A Meta-Analysis. CESifo Working Paper Series, WP No. 2206.

[16] Bourguignon, F. (1996). Comment on "Inequality, Poverty, Growth: where do We Stand?" by Albert Fishlow. In M. Bruno and B. Pleskovic (ed.) Annual World Bank Conference on Development Economics: 46-49.

[17] Calderon C. and A. Chong (2004). Volume and Quality of Infrastructure and the Distribution of Income: an Empirical Investigation. Review of Income and Wealth, 50: 87-106. 
[18] Calderón, C., and L. Servén (2004). The Effects of Development on Growth and Income Distribution. World Bank Policy Research Working Paper No. 3400, The World Bank.

[19] Calderón, C., and L. Servén (2014). Infrastructure, Growth, and Inequality. World Bank Policy Research Working Paper Series 7034.

[20] Chetty, R., and N. Hendren (2015). The Effects of Neighborhoods on Intergenerational Mobility: Childhood Exposure Effects and County Level Estimates. Harvard University mimeo.

[21] Cohen, L., J. Coval, and C.J. Malloy (2011). Do Powerful Politicians Cause Corporate Downsizing? Journal of Political Economy, 119: 1015-1060.

[22] d'Hombres, B., A. Weber, and L. Elia (2012). Literature Review on Inequality and the Impact on Social Outcomes. European Commission. JRC Scientific and Policy Reports.

[23] Dupor, B., and M. Mehkari (2015). Schools and Stimulus. St Louis Fed Working Paper 2015004 .

[24] Ehrhart, C. (2009) The Effects of Inequality on Growth: a Survey of the Theoretical and Empirical Literature. ECINEQ, February, WP 2009-107.

[25] Estache, A., and M. Fay (2007). Current Debates on Infrastructure Policy. World Bank Policy Research Working Paper Series 4410.

[26] Fields, G.S. (2001) Distribution and Development: A New Look at the Developing World. Russell Sage Foundation, New York: The MIT Press.

[27] Forbes, K. (2000). A Reassessment of the Relationship Between Inequality and Growth. American Economic Review, 90: 869-887.

[28] Frank, M. (2009). Inequality and Growth in the United States: Evidence from a New StateLevel Panel of Income Inequality Measure. Economic Inquiry, 47: 55-68.

[29] Galor, O. and J. Zeira (1993). Income Distribution and Macroeconomics. Review of Economic Studies, 60: 35-52.

[30] Gibson, J. and F. Roja (2014). A Bridge to Equality: How Investing in Infrastructure Affects the Distribution of Wealth. Georgia State University.

[31] Gutman, J., S. Chattopadhyay, and A. Sy (2015). Financing African Infrastructure : Can the World Deliver? Global Economy and Development at Brookings.

[32] Kaldor, N. (1960). Essays on Value and Distribution. Glencoe, Free Press.

[33] Kanbur, R. and N. Lustig (1999). Why is Inequality Back on the Agenda? Annual World Bank Conference on Development Economics, World Bank, Washington D.C., 28-30 April.

[34] Kanbur, R. and J. Stiglitz (2015). Wealth and Income distribution: New Theories Needed for a New Era. VOX, CEPR's Policy Portal. 18 August.

[35] Kuznets, S. (1955). Economic Growth and Income Inequality. American Economic Review, 45: $1-28$.

[36] Inderst, G. (2010). Infrastructure as an Asset Class. European Investment Bank Papers 1/2010. 
[37] Leduc, S., and D. Wilson (2015). Are State Governments Roadblocks to Federal stimulus? Evidence on the Flypaper Effect of Highway Grants in the 2009 Recovery Act. San Francisco Fed Working Paper 2013-16, forthcoming American Economic Journal: Economic Policy.

[38] Lee, K., E. Miguel, C. Wolfram (2016). Experimental Evidence on the Demand for and Costs of Rural electrification. Working Paper, University of California, Berkeley.

[39] Levy Yeyati, E., A. Micco, and U. Panizza (2004). Should the Government be in the Banking Business? The Role of State-Owned and Development Banks. Inter-American Development Bank, Research Department Publications 4379.

[40] Li, H., and H.-F. Zou (1998). Income Inequality is Not Harmful for Growth: Theory and Evidence. Review of Development Economics, 2: 318-34.

[41] Milanovic, B. (2016). Global Inequality, A New Approach for the Age of Globalization. Harvard University Press.

[42] Peters, S. (2017). Sovereign Wealth Funds and Long-term Investors in Infrastructure: Why the Glaring Absence?, in Frontiers of Sovereign Investment, Rietveld, M., Toledano, P. (Eds.). Columbia University Press.

[43] Peters, S., and P. Pintus (2016). Migrants and Europeans Need EU Commitment to Infrastructure Investment. Op Ed available at https://drive.google.com/file/d/ OB7XzaoR1GnZSN3JmSmg4XOwy cGM/view?usp=sharing.

[44] Piketty, T. (1997). The Dynamics of the Wealth Distribution and the Interest Rate with Credit Rationing. Review of Economic Studies, 64: 173-189.

[45] Piketty, T. (2014). Capital in the 21st Century. Harvard University Press.

[46] Piketty, T., E. Saez, G. Zucman (2016). Distributional National Accounts: Methods and Estimates for the United States. NBER Working Paper 22945.

[47] Romp, W., and J. De Haan (2007). Public Capital and Economic Growth: a Critical Survey. Perspektiven der Wirtschaftspolitik, 8: 6-52.

[48] Ruggles, S., Genadek, K., Goeken, R., Grover, J., and Sobek, M. (2015). Integrated Public Use Microdata Series: Version 6.0 [Machine-readable database]. Minneapolis: University of Minnesota.

[49] Stiglitz, J. E. (2012). The Price of Inequality: how Today's Divided Society Endangers our Future (first edition). Norton \& Company Publishers, New York.

[50] Stern, N. (1991). The Determinants of Growth. Economic Journal 101: 122-133.

[51] van der Weide, R., and B. Milanovic (2014). Inequality is Bad for Growth of the Poor. World Bank Policy Research Working Paper Series 6963.

[52] Wolff, E., and A. Zacharias (2007). The Distributional Consequences of Government Spending and Taxation in the US, 1989 and 2000. Review of Income and Wealth 53: 692-715. 


\section{Appendix}

\subsection{Robustness of Regression Results}

In this section, we report additional results, first from regressions with both level and growth rate of infrastructure spending (Tables 5-7), second from regressions with state fixed effects but no year fixed effects (Tables 8-10), and finally from standard OLS regressions without any fixed effects (Tables 11-13).

Table 5: Effect of Highways Spending Growth Rate and Level on Inequality - State \& Year Fixed Effects

\begin{tabular}{|c|c|c|c|}
\hline & $\begin{array}{c}(1) \\
\text { Total Gini }\end{array}$ & $\begin{array}{c}(2) \\
\text { Bottom Gini }\end{array}$ & $\begin{array}{c}(3) \\
\text { Top Gini }\end{array}$ \\
\hline Highways Growth Rate & $\begin{array}{c}-0.032^{* * *} \\
(0.008)\end{array}$ & $\begin{array}{c}-0.027^{* *} \\
(0.010)\end{array}$ & $\begin{array}{c}-0.022^{* * *} \\
(0.005)\end{array}$ \\
\hline Highways Level & $\begin{array}{c}0.000 \\
(0.000)\end{array}$ & $\begin{array}{c}-0.000^{* *} \\
(0.000)\end{array}$ & $\begin{array}{c}0.000^{* *} \\
(0.000)\end{array}$ \\
\hline Under Age 15 & $\begin{array}{c}0.739^{* * *} \\
(0.113)\end{array}$ & $\begin{array}{c}0.494^{* * *} \\
(0.103)\end{array}$ & $\begin{array}{c}0.444^{* * *} \\
(0.076)\end{array}$ \\
\hline Over Age 65 & $\begin{array}{c}0.434^{* * *} \\
(0.113)\end{array}$ & $\begin{array}{c}0.352^{* * *} \\
(0.110)\end{array}$ & $\begin{array}{c}0.263^{* * *} \\
(0.086)\end{array}$ \\
\hline Education Shortfall & $\begin{array}{c}0.045^{* * *} \\
(0.015)\end{array}$ & $\begin{array}{c}0.051^{* * *} \\
(0.017)\end{array}$ & $\begin{array}{l}0.015^{*} \\
(0.008)\end{array}$ \\
\hline College & $\begin{array}{c}0.398^{* * *} \\
(0.083)\end{array}$ & $\begin{array}{c}0.512^{* * *} \\
(0.085)\end{array}$ & $\begin{array}{c}0.142^{* *} \\
(0.058)\end{array}$ \\
\hline Constant & $\begin{array}{l}0.072^{*} \\
(0.043)\end{array}$ & $\begin{array}{l}-0.013 \\
(0.038)\end{array}$ & $\begin{array}{c}0.063^{* *} \\
(0.029)\end{array}$ \\
\hline Observations & 306 & 306 & 306 \\
\hline$R^{2}$ & 0.824 & 0.641 & 0.900 \\
\hline State fixed effects & Yes & Yes & Yes \\
\hline Time fixed effects & Yes & Yes & Yes \\
\hline
\end{tabular}

\subsection{State-Level Summary Statistics}

Figures 8 and 9 report the average annual real growth rates for highways and higher education, respectively, state by state and over the six time periods, where the year indicated at the top of each column is the end year of the decade. For example, the average real growth rate of higher education in Alabama from 1950 to 1960 was 5.1\% in Figure 9.

\subsection{Counterfactual Exercise: Quartiles}

Figures 10 to 13 report the details of the counterfactual analysis, in terms of quartiles. 
Table 6: Effect of Higher Education Spending Growth Rate and Level on Inequality - State \& Year Fixed Effects

\begin{tabular}{lccc}
\hline \hline & $(1)$ & $(2)$ & $(3)$ \\
& Total Gini & Bottom Gini & Top Gini \\
\hline Higher Ed. Growth Rate & $-0.015^{* * *}$ & $-0.019^{* * *}$ & $-0.014^{* *}$ \\
& $(0.006)$ & $(0.004)$ & $(0.006)$ \\
Higher Ed. Level & $0.000^{* * *}$ & -0.000 & $0.000^{* * *}$ \\
& $(0.000)$ & $(0.000)$ & $(0.000)$ \\
Under Age 15 & $0.648^{* * *}$ & $0.436^{* * *}$ & $0.399^{* * *}$ \\
& $(0.108)$ & $(0.104)$ & $(0.073)$ \\
& & & \\
Over Age 65 & $0.397^{* * *}$ & $0.320^{* * *}$ & $0.222^{* *}$ \\
& $(0.114)$ & $(0.114)$ & $(0.087)$ \\
Education Shortfall & $0.047^{* * *}$ & $0.052^{* * *}$ & $0.014^{*}$ \\
& $(0.015)$ & $(0.018)$ & $(0.007)$ \\
College & & & \\
& $0.367^{* * *}$ & $0.472^{* * *}$ & $0.113^{*}$ \\
Constant & $(0.087)$ & $(0.079)$ & $(0.064)$ \\
& & & \\
& $0.104^{* *}$ & 0.008 & $0.083^{* * *}$ \\
Observations & $(0.044)$ & $(0.038)$ & $(0.031)$ \\
$R^{2}$ & 306 & 306 & 306 \\
State fixed effects & 0.831 & 0.632 & 0.904 \\
Time fixed effects & Yes & Yes & Yes \\
\hline \hline Robust standard errors in parentheses. & & Yes \\
$* p<0.10,{ }^{* *} p<0.05, * * *$ & $p<0.01$ & & \\
\hline
\end{tabular}

Table 7: Effect of Highways and Higher Education Spending Growth Rate and Level on Inequality - State \& Year Fixed Effects

\begin{tabular}{|c|c|c|c|}
\hline & $\begin{array}{c}(1) \\
\text { Total Gini }\end{array}$ & $\begin{array}{c}(2) \\
\text { Bottom Gini }\end{array}$ & $\begin{array}{c}(3) \\
\text { Top Gini }\end{array}$ \\
\hline Higher Ed. Growth Rate & $\begin{array}{c}-0.012^{* * *} \\
(0.004)\end{array}$ & $\begin{array}{c}-0.017^{* *} \\
(0.006)\end{array}$ & $\begin{array}{c}-0.012^{* * *} \\
(0.003)\end{array}$ \\
\hline Highways Growth Rate & $\begin{array}{c}-0.028^{* * *} \\
(0.010)\end{array}$ & $\begin{array}{c}-0.022^{*} \\
(0.013)\end{array}$ & $\begin{array}{c}-0.019^{* * *} \\
(0.007)\end{array}$ \\
\hline Higher Ed. Level & $\begin{array}{c}0.000^{* * *} \\
(0.000)\end{array}$ & $\begin{array}{c}0.000 \\
(0.000)\end{array}$ & $\begin{array}{c}0.000^{* * *} \\
(0.000)\end{array}$ \\
\hline Highways Level & $\begin{array}{c}-0.000^{* * *} \\
(0.000)\end{array}$ & $\begin{array}{c}-0.000^{* * *} \\
(0.000)\end{array}$ & $\begin{array}{l}-0.000 \\
(0.000)\end{array}$ \\
\hline Under Age 15 & $\begin{array}{c}0.667^{* * *} \\
(0.102)\end{array}$ & $\begin{array}{c}0.460^{* * *} \\
(0.099)\end{array}$ & $\begin{array}{c}0.403^{* * *} \\
(0.069)\end{array}$ \\
\hline Over Age 65 & $\begin{array}{c}0.398^{* * *} \\
(0.114)\end{array}$ & $\begin{array}{c}0.312^{* * *} \\
(0.110)\end{array}$ & $\begin{array}{c}0.232^{* * *} \\
(0.086)\end{array}$ \\
\hline Education Shortfall & $\begin{array}{c}0.045^{* * *} \\
(0.015)\end{array}$ & $\begin{array}{c}0.048^{* * *} \\
(0.017)\end{array}$ & $\begin{array}{l}0.014^{*} \\
(0.007)\end{array}$ \\
\hline College & $\begin{array}{c}0.386^{* * *} \\
(0.093)\end{array}$ & $\begin{array}{c}0.487^{* * *} \\
(0.087)\end{array}$ & $\begin{array}{l}0.126^{*} \\
(0.066)\end{array}$ \\
\hline Constant & $\begin{array}{c}0.103^{* *} \\
(0.042)\end{array}$ & $\begin{array}{c}0.006 \\
(0.037)\end{array}$ & $\begin{array}{c}0.083^{* * *} \\
(0.029)\end{array}$ \\
\hline Observations & 306 & 306 & 306 \\
\hline$R^{2}$ & 0.839 & 0.650 & 0.907 \\
\hline State fixed effects & Yes & Yes & Yes \\
\hline Time fixed effects & Yes & Yes & Yes \\
\hline
\end{tabular}


Table 8: Effect of Highways Spending on Inequality - No Year Fixed Effects

\begin{tabular}{lccc}
\hline \hline & $(1)$ & $(2)$ & $(3)$ \\
& Total Gini & Bottom Gini & Top Gini \\
\hline Highways & -0.012 & $-0.037^{* * *}$ & 0.015 \\
& $(0.017)$ & $(0.010)$ & $(0.019)$ \\
Under Age 15 & $0.763^{* * *}$ & $0.387^{* * *}$ & $0.584^{* * *}$ \\
& $(0.061)$ & $(0.052)$ & $(0.065)$ \\
Over Age 65 & $0.876^{* * *}$ & $0.295^{* * *}$ & $0.898^{* * *}$ \\
& $(0.152)$ & $(0.103)$ & $(0.165)$ \\
Education Shortfall & $0.045^{* * *}$ & $0.038^{* * *}$ & $0.034^{* * *}$ \\
& $(0.013)$ & $(0.013)$ & $(0.010)$ \\
College & & & \\
& $0.870^{* * *}$ & $0.593^{* * *}$ & $0.602^{* * *}$ \\
Constant & $(0.073)$ & $(0.052)$ & $(0.072)$ \\
& & & \\
\hline Observations & 0.001 & 0.032 & $-0.079^{* *}$ \\
$R^{2}$ & $(0.032)$ & $(0.026)$ & $(0.035)$ \\
State fixed effects & 306 & 306 & 306 \\
Time fixed effects & 0.685 & 0.559 & 0.537 \\
\hline \hline Robust standar & Yes & Yes & Yes \\
& No & No & No \\
\hline
\end{tabular}

Robust standard errors in parentheses.

${ }^{*} p<0.10,{ }^{* *} p<0.05,{ }^{* * *} p<0.01$

Table 9: Effect of Higher Education Spending on Inequality - No Year Fixed Effects

\begin{tabular}{lccc}
\hline \hline & $(1)$ & $(2)$ & $(3)$ \\
& Total Gini & Bottom Gini & Top Gini \\
\hline Highways & 0.009 & $-0.021^{* * *}$ & 0.019 \\
& $(0.015)$ & $(0.006)$ & $(0.012)$ \\
Under Age 15 & $0.742^{* * *}$ & $0.341^{* * *}$ & $0.598^{* * *}$ \\
& $(0.061)$ & $(0.047)$ & $(0.059)$ \\
Over Age 65 & $0.867^{* * *}$ & $0.255^{* *}$ & $0.916^{* * *}$ \\
& $(0.148)$ & $(0.107)$ & $(0.160)$ \\
Education Shortfall & $0.047^{* * *}$ & $0.033^{* *}$ & $0.040^{* * *}$ \\
& $(0.014)$ & $(0.014)$ & $(0.010)$ \\
College & & & \\
& $0.867^{* * *}$ & $0.550^{* * *}$ & $0.626^{* * *}$ \\
Constant & $(0.071)$ & $(0.047)$ & $(0.064)$ \\
& & & \\
\hline Observations & 0.005 & $0.056^{* *}$ & $-0.091^{* * *}$ \\
$R^{2}$ & $(0.030)$ & $(0.026)$ & $(0.032)$ \\
State fixed effects & 306 & 306 & 306 \\
Time fixed effects & 0.685 & 0.553 & 0.542 \\
\hline \hline & Yes & Yes & Yes \\
Robut standard & No & No & \\
\hline
\end{tabular}

Robust standard errors in parentheses.

${ }^{*} p<0.10,{ }^{* *} p<0.05,{ }^{* * *} p<0.01$ 
Table 10: Effect of Highways and Higher Education Spending on Inequality - No Year Fixed Effects

\begin{tabular}{lccc}
\hline \hline & $(1)$ & $(2)$ & $(3)$ \\
& Total Gini & Bottom Gini & Top Gini \\
\hline Higher Education & 0.010 & $-0.017^{* * *}$ & 0.018 \\
& $(0.013)$ & $(0.006)$ & $(0.014)$ \\
Highways & -0.014 & $-0.033^{* *}$ & 0.011 \\
& $(0.018)$ & $(0.012)$ & $(0.019)$ \\
Under Age 15 & $0.762^{* * *}$ & $0.388^{* * *}$ & $0.583^{* * *}$ \\
& $(0.061)$ & $(0.056)$ & $(0.067)$ \\
Over Age 65 & $0.881^{* * *}$ & $0.287^{* *}$ & $0.906^{* * *}$ \\
& $(0.155)$ & $(0.110)$ & $(0.170)$ \\
Education Shortfall & $0.048^{* * *}$ & $0.034^{* *}$ & $0.039^{* * *}$ \\
& $(0.014)$ & $(0.013)$ & $(0.011)$ \\
College & & & \\
& $0.879^{* * *}$ & $0.578^{* * *}$ & $0.617^{* * *}$ \\
Constant & $(0.065)$ & $(0.052)$ & $(0.060)$ \\
& & & \\
Time fixed effects & -0.003 & 0.038 & $-0.086^{* *}$ \\
\hline \hline Observations & $(0.032)$ & $(0.029)$ & $(0.037)$ \\
\hline Robust standara & 306 & 306 & 306 \\
& 0.686 & 0.566 & 0.542 \\
Yes & Yes & Nos \\
\hline
\end{tabular}

Robust standard errors in parentheses.

${ }^{*} p<0.10,{ }^{* *} p<0.05,{ }^{* * *} p<0.01$

Table 11: Effect of Highways Spending on Inequality - No Fixed Effects

\begin{tabular}{lccc}
\hline \hline & $(1)$ & $(2)$ & $(3)$ \\
& Total Gini & Bottom Gini & Top Gini \\
\hline Highways & 0.015 & -0.013 & $0.031^{*}$ \\
& $(0.025)$ & $(0.020)$ & $(0.018)$ \\
Under Age 15 & $0.237^{* * *}$ & -0.003 & $0.258^{* * *}$ \\
& $(0.089)$ & $(0.072)$ & $(0.065)$ \\
Over Age 65 & $0.399^{* * *}$ & $0.158^{*}$ & $0.471^{* * *}$ \\
& $(0.114)$ & $(0.093)$ & $(0.084)$ \\
Education Shortfall & $0.119^{* * *}$ & $0.102^{* * *}$ & $0.064^{* * *}$ \\
& $(0.014)$ & $(0.011)$ & $(0.010)$ \\
College & & & \\
& $0.654^{* * *}$ & $0.363^{* * *}$ & $0.470^{* * *}$ \\
Constant & $(0.067)$ & $(0.054)$ & $(0.049)$ \\
& & & \\
\hline Observations & $0.167^{* * *}$ & $0.132^{* * *}$ & 0.050 \\
$R^{2}$ & $(0.041)$ & $(0.034)$ & $(0.030)$ \\
State fixed effects & 306 & 306 & 306 \\
Time fixed effects & 0.355 & 0.299 & 0.348 \\
\hline \hline Standard No & No & No & No \\
\hline
\end{tabular}

Standard errors in parentheses.

OLS estimation without any fixed effects.

${ }^{*} p<0.10,{ }^{* *} p<0.05,{ }^{* * *} p<0.01$ 
Table 12: Effect of Higher Education Spending on Inequality - No Fixed Effects

\begin{tabular}{|c|c|c|c|}
\hline & $\begin{array}{c}(1) \\
\text { Total Gini }\end{array}$ & $\begin{array}{c}\text { (2) } \\
\text { Bottom Gini }\end{array}$ & $\begin{array}{c}(3) \\
\text { Top Gini }\end{array}$ \\
\hline Higher Education & $\begin{array}{l}0.028^{*} \\
(0.016)\end{array}$ & $\begin{array}{l}-0.009 \\
(0.013)\end{array}$ & $\begin{array}{c}0.023^{* *} \\
(0.012)\end{array}$ \\
\hline Under Age 15 & $\begin{array}{c}0.245^{* * *} \\
(0.085)\end{array}$ & $\begin{array}{l}-0.014 \\
(0.069)\end{array}$ & $\begin{array}{c}0.283^{* * *} \\
(0.063)\end{array}$ \\
\hline Over Age 65 & $\begin{array}{c}0.409^{* * *} \\
(0.112)\end{array}$ & $\begin{array}{c}0.149 \\
(0.092)\end{array}$ & $\begin{array}{c}0.494^{* * *} \\
(0.083)\end{array}$ \\
\hline Education Shortfall & $\begin{array}{c}0.121^{* * *} \\
(0.014)\end{array}$ & $\begin{array}{c}0.102^{* * *} \\
(0.011)\end{array}$ & $\begin{array}{c}0.065^{* * *} \\
(0.010)\end{array}$ \\
\hline College & $\begin{array}{c}0.663^{* * *} \\
(0.066)\end{array}$ & $\begin{array}{c}0.357^{* * *} \\
(0.054)\end{array}$ & $\begin{array}{c}0.484^{* * *} \\
(0.049)\end{array}$ \\
\hline Constant & $\begin{array}{c}0.161^{* * *} \\
(0.040)\end{array}$ & $\begin{array}{c}0.137^{* * *} \\
(0.033)\end{array}$ & $\begin{array}{c}0.038 \\
(0.030)\end{array}$ \\
\hline Observations & 306 & 306 & 306 \\
\hline$R^{2}$ & 0.361 & 0.299 & 0.350 \\
\hline State fixed effects & No & No & No \\
\hline Time fixed effects & No & No & No \\
\hline
\end{tabular}

Table 13: Effect of Highways and Higher Education Spending on Inequality - No Fixed Effects

\begin{tabular}{|c|c|c|c|}
\hline & $\begin{array}{c}(1) \\
\text { Total Gini }\end{array}$ & $\begin{array}{c}(2) \\
\text { Bottom Gini }\end{array}$ & $\begin{array}{c}(3) \\
\text { Top Gini }\end{array}$ \\
\hline Higher Education & $\begin{array}{l}0.027^{*} \\
(0.016)\end{array}$ & $\begin{array}{l}-0.008 \\
(0.013)\end{array}$ & $\begin{array}{l}0.021^{*} \\
(0.012)\end{array}$ \\
\hline Highways & $\begin{array}{c}0.010 \\
(0.025)\end{array}$ & $\begin{array}{l}-0.011 \\
(0.020)\end{array}$ & $\begin{array}{c}0.028 \\
(0.018)\end{array}$ \\
\hline Under Age 15 & $\begin{array}{c}0.234^{* * *} \\
(0.088)\end{array}$ & $\begin{array}{l}-0.003 \\
(0.072)\end{array}$ & $\begin{array}{c}0.256^{* * *} \\
(0.065)\end{array}$ \\
\hline Over Age 65 & $\begin{array}{c}0.400^{* * *} \\
(0.114)\end{array}$ & $\begin{array}{l}0.158^{*} \\
(0.093)\end{array}$ & $\begin{array}{c}0.471^{* * *} \\
(0.084)\end{array}$ \\
\hline Education Shortfall & $\begin{array}{c}0.121^{* * *} \\
(0.014)\end{array}$ & $\begin{array}{c}0.101^{* * *} \\
(0.011)\end{array}$ & $\begin{array}{c}0.065^{* * *} \\
(0.010)\end{array}$ \\
\hline College & $\begin{array}{c}0.659^{* * *} \\
(0.067)\end{array}$ & $\begin{array}{c}0.361^{* * *} \\
(0.055)\end{array}$ & $\begin{array}{c}0.474^{* * *} \\
(0.049)\end{array}$ \\
\hline Constant & $\begin{array}{c}0.164^{* * *} \\
(0.041)\end{array}$ & $\begin{array}{c}0.133^{* * *} \\
(0.034)\end{array}$ & $\begin{array}{c}0.048 \\
(0.030)\end{array}$ \\
\hline Observations & 306 & 306 & 306 \\
\hline$R^{2}$ & 0.361 & 0.300 & 0.355 \\
\hline State fixed effects & No & No & No \\
\hline Time fixed effects & No & No & No \\
\hline
\end{tabular}

Standard errors in parentheses.

OLS estimation without any fixed effects.

${ }^{*} p<0.10,{ }^{* *} p<0.05,{ }^{* * *} p<0.01$ 
Figure 8: Average Real Growth Rate of Spending on Highways

\begin{tabular}{|c|c|c|c|c|c|c|}
\hline State & 1960 & 1970 & 1980 & 1990 & 2000 & 2008 \\
\hline Alabama & 0.203 & 0.020 & -0.023 & 0.040 & 0.055 & 0.026 \\
\hline Alaska & -0.440 & 0.282 & 0.003 & 0.011 & 0.074 & 0.107 \\
\hline Arizona & 0.127 & 0.053 & 0.018 & 0.138 & -0.009 & 0.018 \\
\hline Arkansas & 0.072 & 0.011 & 0.067 & -0.047 & 0.092 & 0.014 \\
\hline California & 0.137 & 0.069 & -0.106 & 0.050 & 0.034 & 0.128 \\
\hline Colorado & 0.089 & 0.045 & 0.006 & 0.037 & 0.085 & -0.035 \\
\hline Connecticut & 0.157 & 0.019 & -0.056 & 0.164 & -0.027 & -0.041 \\
\hline Delaware & -0.048 & 0.013 & -0.003 & 0.094 & 0.048 & 0.045 \\
\hline Florida & 0.130 & 0.006 & 0.049 & 0.020 & 0.088 & 0.089 \\
\hline Georgia & 0.102 & 0.026 & 0.069 & 0.024 & 0.061 & 0.017 \\
\hline Hawaii & 0.144 & 0.122 & -0.011 & 0.033 & -0.007 & 0.041 \\
\hline Idaho & 0.085 & 0.035 & -0.007 & 0.058 & 0.018 & 0.057 \\
\hline Illinois & 0.252 & 0.000 & 0.028 & 0.019 & -0.008 & 0.102 \\
\hline Indiana & 0.156 & 0.016 & 0.005 & 0.003 & 0.077 & 0.054 \\
\hline Iowa & 0.109 & 0.013 & -0.025 & 0.024 & 0.087 & -0.035 \\
\hline Kansas & 0.113 & 0.004 & 0.032 & -0.002 & 0.085 & 0.003 \\
\hline Kentucky & 0.086 & 0.040 & 0.065 & -0.077 & 0.095 & 0.046 \\
\hline Louisiana & 0.130 & 0.007 & 0.008 & 0.015 & 0.033 & 0.091 \\
\hline Maine & 0.125 & 0.000 & 0.009 & -0.007 & 0.068 & -0.026 \\
\hline Maryland & 0.024 & 0.053 & 0.017 & 0.049 & -0.038 & 0.125 \\
\hline Massachusetts & 0.063 & 0.021 & -0.052 & 0.028 & 0.207 & -0.070 \\
\hline Michigan & 0.183 & -0.004 & 0.003 & -0.007 & 0.040 & 0.011 \\
\hline Minnesota & 0.104 & 0.041 & -0.018 & 0.040 & 0.022 & 0.039 \\
\hline Mississippi & 0.163 & 0.027 & 0.017 & -0.013 & 0.093 & 0.033 \\
\hline Missouri & 0.153 & 0.061 & -0.032 & -0.003 & 0.090 & 0.013 \\
\hline Montana & 0.102 & 0.071 & -0.034 & 0.005 & 0.061 & 0.047 \\
\hline New Hampshire & 0.173 & 0.004 & -0.010 & 0.022 & 0.046 & 0.002 \\
\hline New York & 0.143 & 0.013 & -0.040 & 0.048 & 0.054 & 0.014 \\
\hline Nebraska & 0.130 & 0.009 & 0.035 & 0.014 & 0.070 & 0.001 \\
\hline Nevada & 0.082 & 0.091 & 0.031 & 0.049 & 0.079 & -0.032 \\
\hline New Jersey & -0.017 & 0.127 & -0.122 & 0.144 & -0.017 & 0.090 \\
\hline New Mexico & 0.078 & 0.046 & 0.007 & 0.048 & -0.004 & 0.088 \\
\hline North Carolina & -0.024 & 0.071 & -0.002 & 0.033 & 0.084 & 0.016 \\
\hline North Dakota & 0.147 & -0.032 & 0.015 & -0.002 & 0.084 & 0.015 \\
\hline Ohio & 0.213 & 0.020 & -0.067 & 0.032 & 0.080 & 0.008 \\
\hline Oklahoma & 0.030 & 0.075 & -0.028 & 0.032 & 0.092 & 0.016 \\
\hline Oregon & 0.115 & 0.017 & 0.023 & 0.000 & 0.028 & 0.062 \\
\hline Pennsylvania & 0.003 & 0.089 & -0.145 & 0.116 & 0.045 & 0.104 \\
\hline Rhode Island & 0.153 & 0.012 & -0.081 & 0.150 & 0.007 & -0.076 \\
\hline South Carolina & 0.117 & 0.005 & -0.027 & 0.074 & 0.083 & -0.051 \\
\hline South Dakota & 0.132 & 0.001 & -0.021 & 0.022 & 0.084 & -0.004 \\
\hline Tennessee & 0.115 & 0.025 & 0.002 & 0.042 & 0.046 & -0.003 \\
\hline Texas & 0.144 & 0.031 & 0.034 & 0.008 & 0.064 & 0.054 \\
\hline Utah & 0.136 & 0.075 & 0.001 & -0.003 & 0.102 & 0.026 \\
\hline Vermont & 0.266 & 0.042 & -0.080 & 0.016 & 0.027 & 0.067 \\
\hline Virginia & 0.050 & 0.100 & 0.010 & 0.033 & 0.034 & -0.026 \\
\hline Washington D.C. & -0.244 & 0.027 & -0.137 & 0.134 & -0.127 & 0.082 \\
\hline Washington & 0.067 & 0.074 & 0.014 & -0.002 & 0.045 & 0.105 \\
\hline West Virginia & 0.139 & 0.087 & 0.019 & -0.087 & 0.087 & 0.032 \\
\hline Wisconsin & 0.138 & -0.003 & 0.019 & 0.012 & 0.099 & 0.014 \\
\hline Wyoming & 0.139 & 0.017 & 0.015 & -0.001 & 0.051 & 0.018 \\
\hline
\end{tabular}


Figure 9: Average Real Growth Rate of Spending on Higher Education

\begin{tabular}{|c|c|c|c|c|c|c|}
\hline State & 1960 & 1970 & 1980 & 1990 & 2000 & 2008 \\
\hline Alabama & 0.051 & 0.153 & 0.050 & 0.056 & 0.061 & 0.077 \\
\hline Alaska & -0.894 & 0.204 & 0.092 & 0.010 & 0.042 & 0.073 \\
\hline Arizona & 0.108 & 0.148 & 0.042 & 0.087 & 0.042 & 0.054 \\
\hline Arkansas & 0.044 & 0.111 & 0.048 & 0.061 & 0.080 & 0.062 \\
\hline California & 0.163 & 0.059 & 0.052 & 0.095 & 0.054 & 0.049 \\
\hline Colorado & 0.091 & 0.132 & 0.035 & 0.056 & 0.074 & 0.044 \\
\hline Connecticut & 0.032 & 0.136 & 0.028 & 0.059 & 0.065 & 0.077 \\
\hline Delaware & 0.070 & 0.180 & 0.048 & 0.056 & 0.055 & 0.062 \\
\hline Florida & 0.062 & 0.133 & 0.050 & 0.107 & 0.051 & 0.073 \\
\hline Georgia & 0.203 & 0.160 & 0.016 & 0.072 & 0.088 & 0.080 \\
\hline Hawaii & 0.201 & 0.214 & 0.027 & 0.044 & 0.056 & 0.059 \\
\hline Idaho & 0.017 & 0.130 & 0.045 & 0.056 & 0.074 & 0.082 \\
\hline Illinois & 0.067 & 0.146 & -0.013 & 0.059 & 0.055 & 0.074 \\
\hline Indiana & 0.081 & 0.120 & 0.003 & 0.054 & 0.075 & 0.046 \\
\hline Iowa & 0.051 & 0.120 & 0.021 & 0.057 & 0.044 & 0.045 \\
\hline Kansas & 0.052 & 0.110 & 0.010 & 0.061 & 0.058 & 0.072 \\
\hline Kentucky & 0.085 & 0.153 & 0.046 & 0.045 & 0.069 & 0.084 \\
\hline Louisiana & 0.079 & 0.099 & 0.041 & 0.036 & 0.072 & 0.081 \\
\hline Maine & 0.047 & 0.141 & 0.030 & 0.082 & 0.036 & 0.070 \\
\hline Maryland & 0.064 & 0.144 & 0.036 & 0.073 & 0.071 & 0.084 \\
\hline Massachusetts & 0.091 & 0.198 & 0.006 & 0.080 & 0.063 & 0.083 \\
\hline Michigan & 0.091 & 0.108 & 0.009 & 0.054 & 0.075 & 0.058 \\
\hline Minnesota & 0.054 & 0.122 & 0.010 & 0.048 & 0.068 & 0.066 \\
\hline Mississippi & 0.066 & 0.092 & 0.055 & 0.049 & 0.083 & 0.068 \\
\hline Missouri & 0.067 & 0.151 & 0.013 & 0.049 & 0.075 & 0.065 \\
\hline Montana & 0.073 & 0.081 & 0.008 & 0.034 & 0.107 & 0.089 \\
\hline New Hampshire & 0.079 & 0.135 & 0.024 & 0.047 & 0.071 & 0.079 \\
\hline New York & 0.106 & 0.168 & 0.013 & 0.088 & 0.038 & 0.062 \\
\hline Nebraska & 0.067 & 0.129 & 0.024 & 0.054 & 0.071 & 0.062 \\
\hline Nevada & 0.143 & 0.126 & 0.070 & 0.068 & 0.094 & 0.108 \\
\hline New Jersey & 0.079 & 0.162 & 0.027 & 0.093 & 0.057 & 0.071 \\
\hline New Mexico & 0.052 & 0.121 & 0.025 & 0.066 & 0.074 & 0.078 \\
\hline North Carolina & 0.048 & 0.124 & 0.044 & 0.087 & 0.065 & 0.076 \\
\hline North Dakota & 0.070 & 0.094 & 0.031 & 0.053 & 0.043 & 0.068 \\
\hline Ohio & 0.062 & 0.145 & 0.035 & 0.055 & 0.053 & 0.062 \\
\hline Oklahoma & 0.012 & 0.121 & 0.043 & 0.038 & 0.066 & 0.090 \\
\hline Oregon & 0.093 & 0.127 & 0.031 & 0.032 & 0.077 & 0.075 \\
\hline Pennsylvania & 0.080 & 0.123 & -0.001 & 0.075 & 0.104 & 0.063 \\
\hline Rhode Island & 0.052 & 0.175 & 0.029 & 0.048 & 0.043 & 0.057 \\
\hline South Carolina & 0.062 & 0.138 & 0.093 & 0.057 & 0.061 & 0.078 \\
\hline South Dakota & 0.087 & 0.095 & 0.009 & 0.011 & 0.055 & 0.072 \\
\hline Tennessee & 0.048 & 0.167 & 0.039 & 0.068 & 0.059 & 0.046 \\
\hline Texas & 0.081 & 0.129 & 0.062 & 0.061 & 0.071 & 0.091 \\
\hline Utah & 0.091 & 0.128 & 0.040 & 0.055 & 0.085 & 0.086 \\
\hline Vermont & 0.226 & 0.172 & 0.009 & 0.066 & 0.041 & 0.092 \\
\hline Virginia & 0.062 & 0.129 & 0.065 & 0.071 & 0.054 & 0.091 \\
\hline Washington D.C. & 1.441 & 0.378 & 0.007 & 0.001 & -0.020 & 0.063 \\
\hline Washington & 0.057 & 0.145 & 0.029 & 0.046 & 0.072 & 0.076 \\
\hline West Virginia & 0.048 & 0.123 & 0.014 & 0.036 & 0.062 & 0.077 \\
\hline Wisconsin & 0.069 & 0.159 & 0.010 & 0.039 & 0.052 & 0.067 \\
\hline Wyoming & 0.029 & 0.103 & 0.038 & 0.048 & 0.034 & 0.099 \\
\hline
\end{tabular}


Figure 10: Counterfactual Bottom Gini Variations (in ten thousandth) when States are Given the Median Highways Spending Growth Rate in the 2000s. Upper Panel: Quartile 1. Lower Panel: Quartile 2.
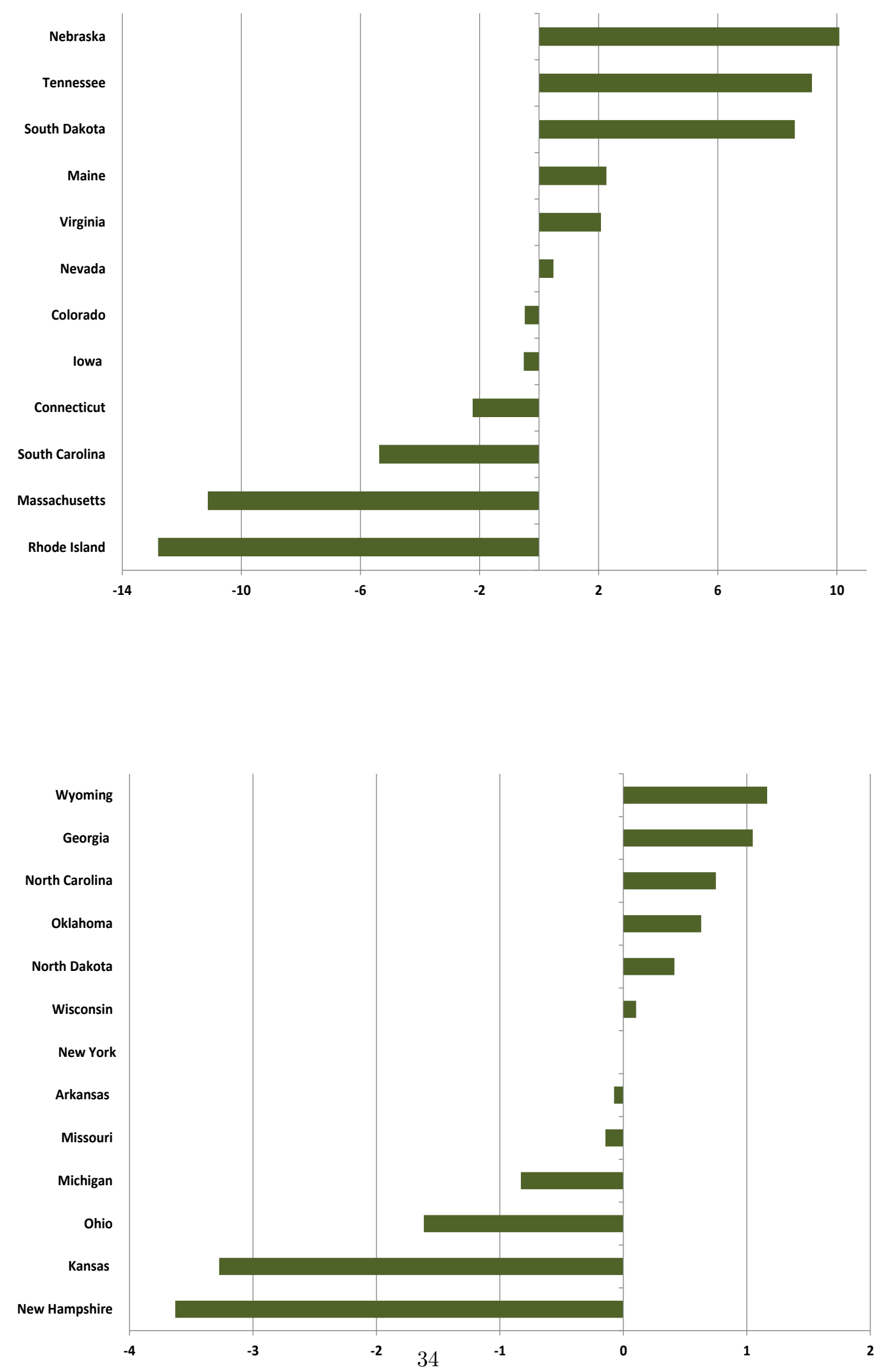
Figure 11: Counterfactual Bottom Gini Variations (in ten thousandth) when States are Given the Median Highways Spending Growth Rate in the 2000s. Upper Panel: Quartile 3. Lower Panel: Quartile 4.
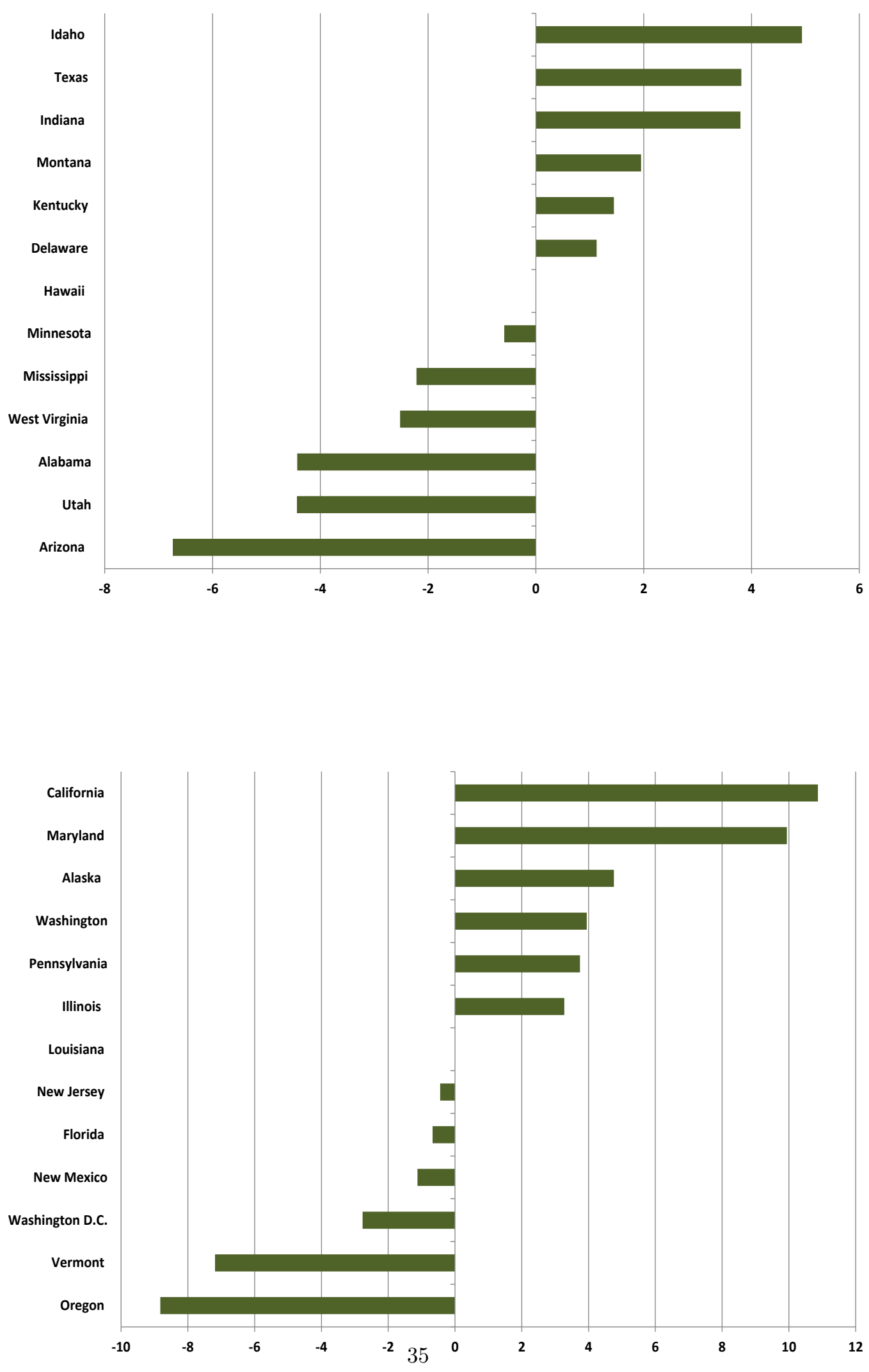
Figure 12: Counterfactual Bottom Gini Variations (in ten thousandth) when States are Given the Median Higher Education Spending Growth Rate in the 2000s. Upper Panel: Quartile 1. Lower Panel: Quartile 2.
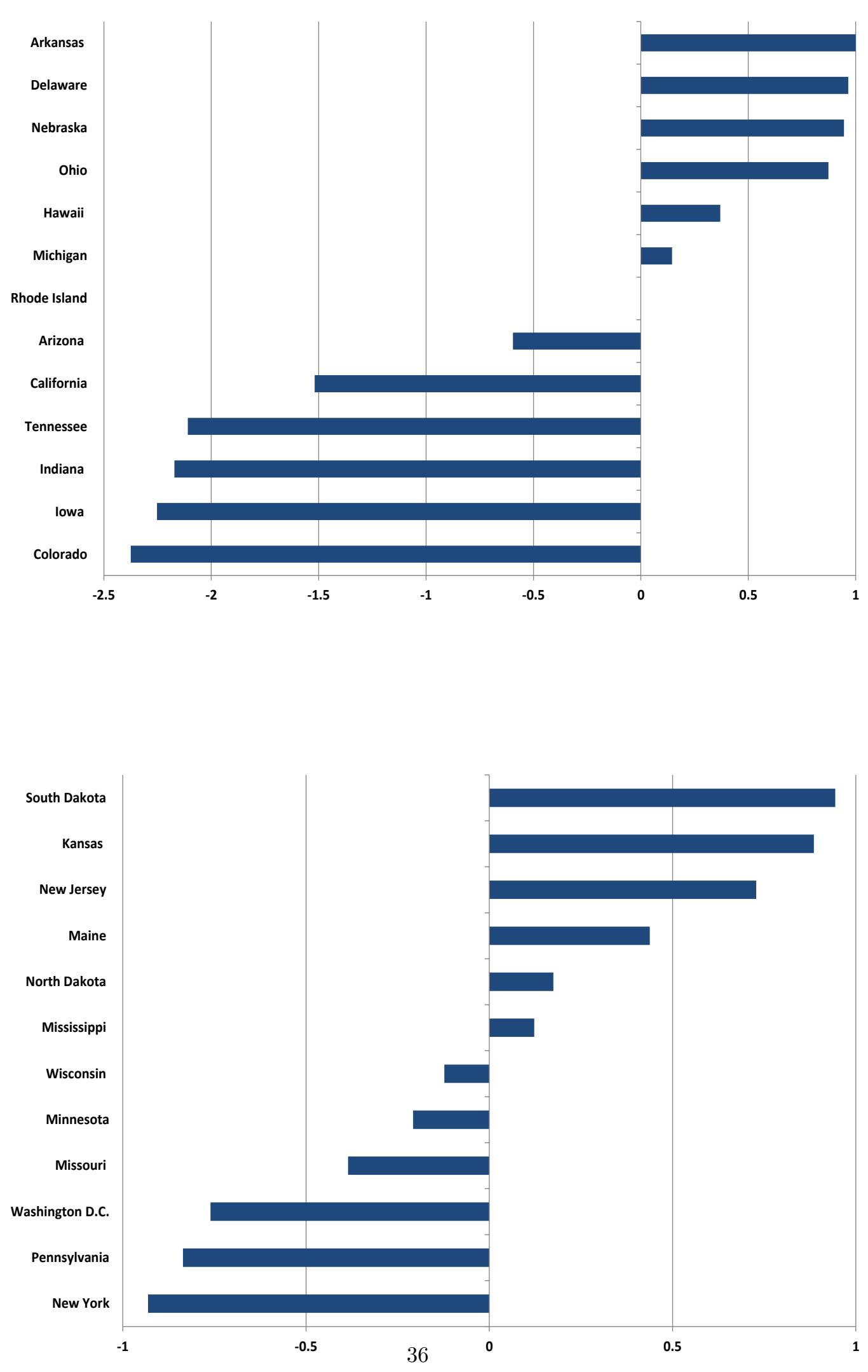
Figure 13: Counterfactual Bottom Gini Variations (in ten thousandth) when States are Given the Median Higher Education Spending Growth Rate in the 2000s. Upper Panel: Quartile 3. Lower Panel: Quartile 4.
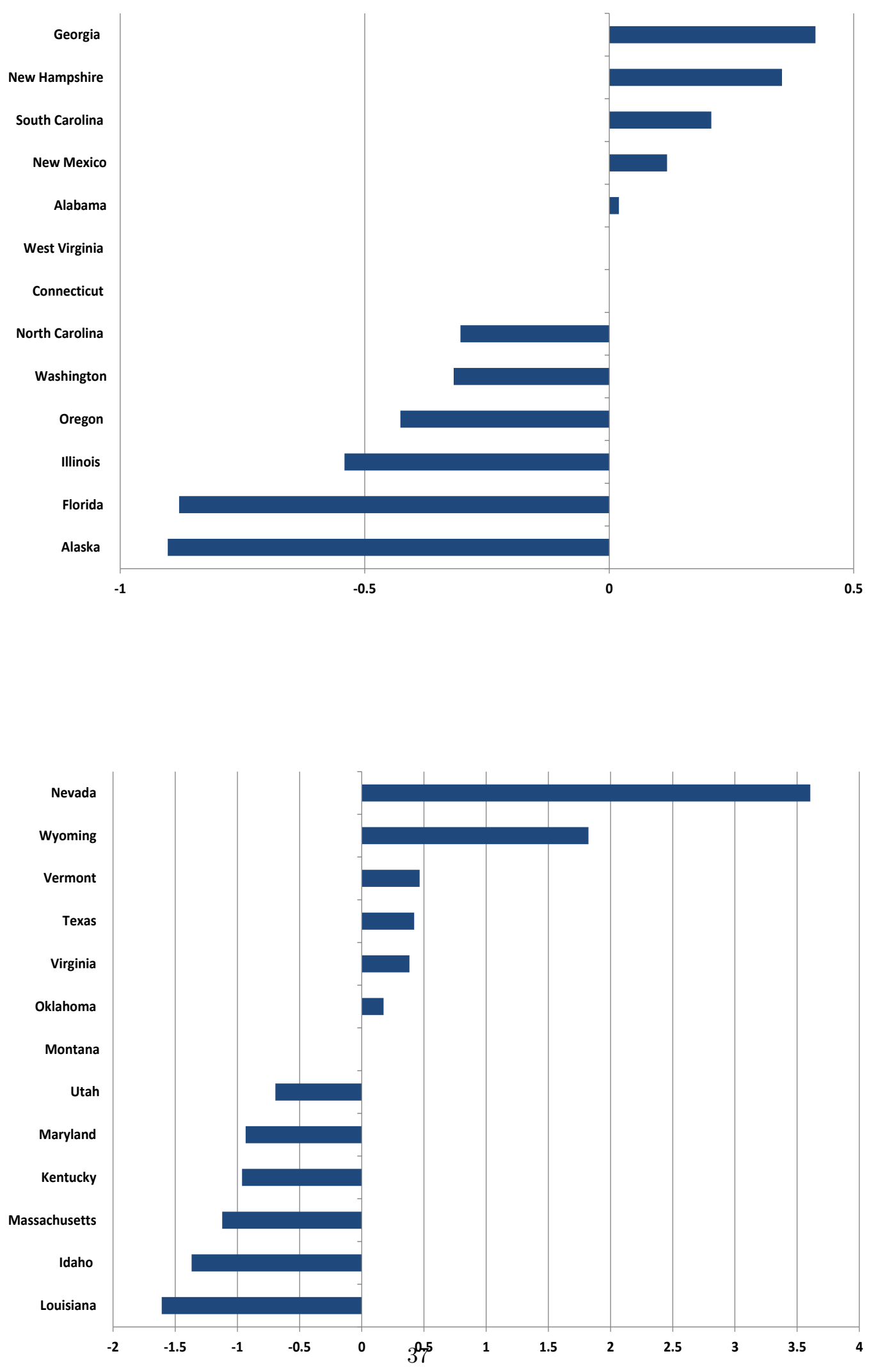